\title{
Impact of natural (waves and currents) and anthropogenic (trawl) resuspension on the export of particulate matter to the open ocean Application to the Gulf of Lion (NW Mediterranean)
}

\author{
B. Ferréa ${ }^{a}$ X. Durrieu de Madron ${ }^{a,{ }^{*}}$, C. Estournel ${ }^{b}, C$. Ulses ${ }^{b}$ and G. Le Corre ${ }^{c}$ \\ ${ }^{a}$ CEFREM, CNRS-Université de Perpignan, Perpignan, France \\ ${ }^{b}$ LA, CNRS-Université de Toulouse, Toulouse, France \\ c IFREMER, DRH, Sète, France
}

*: Corresponding author : X. Durrieu de Madron, Tel.: +33 4686622 48; fax: +33 4686620 96, email address : demadron@univ-perp.fr

\begin{abstract}
:
Modern sediment deposits on continental margins form a vast reservoir of particulate matter that is regularly affected by resuspension processes. Resuspension by bottom trawling on shelves with strong fishing activity can modify the scale of natural disturbance by waves and currents. Recent field data show that the impact of bottom trawls on fine sediment resuspension per unit surface is comparable with that of the largest storms.
\end{abstract}

We assessed the impact of both natural and anthropogenic processes on the dispersal of riverborne particles and shelf sediments on the Gulf of Lion shelf. We performed realistic numerical simulations of resuspension and transport forced by currents and waves or by a fleet of bottom trawlers. Simulations were conducted for a 16-month period (January 1998-April 1999) to characterise the seasonal variability. The sediment dynamics takes into account bed armoring, ripple geometry and the cohesive and non-cohesive characteristics of the sediments. Essential but uncertain parameters (clay content, erosion fluxes and critical shear stress for cohesive sediment) were set with existing data. Resuspension by waves and currents was controlled by shear stress, whereas resuspension by trawls was controlled by density and distribution of the bottom trawler fleet.

Natural resuspension by waves and currents mostly occurred during short seasonal episodes, and was concentrated on the inner shelf. Trawling-induced resuspension, in contrast, occurred regularly throughout the year and was concentrated on the outer shelf. The total annual erosion by trawls $\left(5.6 \times 10^{6} \mathrm{t}^{-1}, \mathrm{t}\right.$ for metric tonnes) was four orders of magnitude lower than the erosion induced by waves and currents $\left(35.3 \times 10^{9} \mathrm{t} \mathrm{y}^{-1}\right)$. However the net resuspension (erosion/deposition budget) for trawling $\left(0.4 \times 10^{6} \mathrm{t} \mathrm{y}^{-1}\right)$ was only one order of magnitude lower than that for waves and currents $\left(9.2 \times 10^{6} \mathrm{t} \mathrm{y}^{-1}\right)$.

Off-shelf export concerned the finest fraction of the sediment (clays and fine silts) and took place primarily at the southwestern end of the Gulf. Off-shelf transport was favoured during the winter 1999 by a very intense episode of dense shelf water cascading. Export of sediment resuspended by trawls $\left(0.4 \times 10^{6} \mathrm{t} \mathrm{y}^{-1}\right)$ was one order of magnitude lower than export associated with natural resuspension $\left(8.5 \times 10^{6} \mathrm{t} \mathrm{y}^{-1}\right)$. Trawling-induced resuspension is thought to represent one-third of the total export of suspended sediment from the shelf.

A simulation combining both resuspension processes reveals no significant changes in resuspension and export rates compared with the sum of each individual process, suggesting the absence of interference between both processes.

Keywords: Sediment dynamics; Sediment transport; Shelf-slope exchanges; Fisheries; Trawling; Mediterranean 


\section{INTRODUCTION}

Continental margins are located at the edges of continents and form a buffer zone where the oceans, continents and atmo sphere interact. Signific ant quantities of organic and inorganic material are input to continental margins where intense hydrodynamic conditions control their dispersal on the shelf and towards the open sea. The sedimentary compartment on continental margins appears to be a vast reservoir of particulate matter, in particular river-derived material, and also of dissolved elements. Resuspension of sediment causes a significant redistribution of sediments and has important implication for regional particulate matter budgets and export to deeper environments, i.e. the continental slope and rise.

Nowadays the physical resuspension and disturbance of sediment on continental shelves is a combination of both natural and anthropogenic mechanisms. Waves and currents are the major initiators of natural disturbance that can result in potentially massive sediment redistribution. The large-scale disturbance they induce can be periodic, when associated with tidal currents, or episodic, when associated with storms. On the other hand, commercial bottom trawling has a more reduced and patchy print. Bottom fishing gears (trawl, dredge) efficiently scrap the superficial sediment and generate suspended sediment plumes. In many shelves fishing intensity is high and most fishable grounds, which can extend to $1000 \mathrm{~m}$ in depth, are likely to be disturbed more or less frequently. The effect of sediment resuspension by waves and currents and bottom trawling is site-specific, as it depends on hydrodynamic conditions (storm frequency and intensity, tidal motions), sediment characteristics (grain size, cohesiveness), and fishing activity (frequency and geographical distribution of bottom hauls, gear type).

The relative contribution of each mechanism to the resuspension and export of sediment on continental shelves has seldom been addressed. To our knowledge, Churchill (1989) and DeAlteris et al. (1999) carried out the only preliminary studies on the comparison of the effect of natural and anthropogenic resuspension on different areas of the Mid-Atlantic Bight (Narraganset Bay, Nantucket Shoals, and Virginia Shelf). These studies concluded that natural physical processes are the primary suspension mechanism in shallow environments, where they disturb the bed regularly, while trawling appears to be the primary resuspension mechanism in deeper environments where natural processes are weaker and rarely capable to erode sediment. Furthermore, Churchill (1989) estimated, using current meter data and simple analytical models, that transport of sediment resuspended by trawlers on muddy regions of the outer shelf could contribute to the off-shelf transport of particulate matter.

The present paper aims to assess the impact of sediment resuspension on particulate matter budgets on the Gulf of Lion continental shelf (NW Mediterranean). It discriminates the impact of natural physical (waves and currents) and anthropogenic (bottom trawling) processes, and thereby check whether anthropogenic disturbance represents a significant or just a slight modification in the scale of existing natural disturbance. This work uses three-dimensional numerical models coupling the 
hydrodynamics with the sediment dynamics, associated with waves and currents and/or trawling. The characteristics of the models are based on experimental studies of the resuspension of fine sediments by intense storms (Ferré et al., 2005; Ulses et al., submitted) and trawls (Durrieu de Madron et al., 2005). Simulations over one annual period, using realistic forcings, were carried out to characterise and quantify (i) the temporal variability and magnitude of sediment resuspension on the shelf, (ii) the dispersal of resuspended sediment, and (iii) the export towards the open sea.

The outline of this paper is as follow: the regional setting is described in section 2 , the hydrodynamical and sediment transport models are briefly described in section 3, the numerical simulations of sediment resuspension and export are exposed in section 4, comparison of resuspension processes and their impact of the sediment budgets are presented in section 5 , a summary is given in section 6 , and the model equations are given in the appendix.

\section{REGIONAL SETTING}

\subsection{Physiography and hydrodynamics}

The Gulf of Lion is a non-tidal and river-dominated margin in the northwestern Mediterranean (Fig. 1a). It is fed by ten rivers, one of them being the Rhône, which is the major Mediterranean river. Its crescent shape and the circulation patterns favour off-shelf export of particulate matter at the southwestern end of the Gulf (Monaco et al., 1999; Heussner et al., 2006, Palanques et al., 2006).

The grain size distribution of superficial bottom sediments is shown in Fig. 1b. Sands of the inner shelf display a seaward-fining texture and merge with mid-shelf muds in water deeper than 20-30 m. The only noticeable exception is the prodeltaic accumulation zones found near river mouths, which are composed of silty muds. Muddy deposits on the outer shelf $(>90 \mathrm{~m})$ are mixed with relict sandy outcrops.

The different wind regimes determine the natural resuspension and transport of suspended sediment on the shelf. N-NW winds induced distinctive and opposite circulation cells on the shelf, favouring intrusion of slope waters in the eastern and central parts, and export of shelf water at the southwestern end of the Gulf (Estournel et al., 2003; Petrenko et al., 2004). Furthermore, these cold and dry continental winds are responsible for the strong cooling and homogenisation of the shelf water column during winter, and eventually generate dense water (Dufau-Julliand et al., 2004; Ulses et al., accepted). Due to the reduced fetch, N-NW winds generate small waves (significant wave height $<2 \mathrm{~m}$, peak period $<6 \mathrm{~s}$ ) on the inner shelf. Conversely, E-SE winds are episodic and short-lived, but are associated with a long fetch and large swell (significant wave height up to $10 \mathrm{~m}$, peak period up to $12 \mathrm{~s})$. River floods often occur in conjunction with E-SE storms as the transport of humid marine air over coastal relief induces abundant precipitations. Resuspension by natural physical processes 
results primarily from the effect of southea sterly swells associated with E-SE winds (Ferré et al., 2005, Guillén et al., 2006).

A permanent cyclonic current (the Northern Current) flows along the slope and is part of the general circulation of the western Mediterranean basin (Millot, 1999). It forms a density front that separates the low-salinity shelf water from the more saline open sea water, limiting the off-shelf dispersal while enhancing along-slope dispersal (Durrieu de Madron et al., 1990; Lapouyade and Durrieu de Madron, 2001).

\subsection{Characteristics of trawling activity}

About 128 trawlers coming from the local fishing ports (Port-Vendres, Port-la-Nouvelle, Agde, Sète, Grau du Roi, Port de Bouc) are working in the Gulf of Lion, using either semi-pelagic or bottom trawls to catch demersal fish species. Bottom trawler use single trawl nets tightened between doors (otter) with a tickler chain as a groundrope. Pelagic trawls are sometimes also used very near the seabed, but Durrieu de Madron et al. (2005) showed that they had no impact on the sediment resuspension. The daily number of trawlers using bottom trawls ranges approximately between 40 and 90 boats, each trawler performing 4 to 5 tows of about 2 hours daily. They work throughout the year except weekends and public holidays.

Fishing grounds cover the whole continental shelf except a 3-miles coastal band, where all trawling activity is banned. A survey conducted with fishermen revealed that the wind is the principal criterion for the choice of the fishing grounds. Trawlers remain basically close to the coast during strong winds (> $10 \mathrm{~m} \mathrm{~s}^{-1}$ or $20 \mathrm{knots}$ ) and rough seas state periods, and move to the outer shelf for weaker winds and calmer sea state (Fig. 2).

\section{MATERIAL AND METHODS}

\subsection{Hydrodynamical model}

The SYMPHONIE Model - The three-dimensional primitive equation coastal ocean model SYMPHONIE, used in this study, has been extensively validated in the Gulf of Lion. It was previously used to study the Rhône river plume (Estournel et al., 1997; Marsaleix et al., 1998; Estournel et al., 2001), the intrusion of the Northern Current into the shelf (Petrenko et al., 2004), the wind-induced circulation (Estournel et al., 2003) and the formation of dense water on the shelf and its cascading over the slope (Dufau-Julliand et al., 2004; Ulses et al., accepted). 
The three current components, free surface elevation, temperature and salinity are computed on a C staggered-grid (Arakawa and Suarez, 1983). A generalized topography following co-ordinate system is used. Compared to simple sigma coordinate, the generalized sigma coordinate allows the slope of the iso-level surface to be limited over steep topography in order to avoid large truncation errors on the pressure gradient computation (Auclair et al., 2000). The turbulence closure scheme is based on a prognostic equation for the turbulent kinetic energy and on a diagnostic equation for the mixing and dissipation length scales (Bougeault and Lacarrère, 1989). A leap frog scheme is used for the timestepping. A time-splitting technique (Blumberg and Mellor, 1987) allows the vertical shear of the current and the depth-averaged horizontal components to be computed separately with appropriate time steps.

Initialisation and boundary conditions - The domain of the Gulf of Lion model (25 vertical levels and 3 $\mathrm{km}$ horizontal resolution grid) is presented in Figure 1a. The main boundary of the modelling domain has been chosen to be parallel to the continental slope.

At the surface, the momentum flux is equal to the wind stress. The heat flux results from the atmospheric fluxes (sensible and latent heat fluxes) and from the radiative fluxes (both short and long wavelengths), the salinity flux is calculated from evaporation. Concerning the flux of turbulent kinetic energy, the usual boundary-layer balance between production and dissipation is applied. The wind stress and the heat fluxes are computed with the bulk formulae (Geernaert, 1990) using 6-hours outputs of the high resolution meteorological models ARPEGE and ALADIN from Météo-France (surface pressure, air temperature, relative humidity and wind velocity) and the sea surface temperature is computed by the ocean model.

At the sea floor, the near-bottom stress is related to the horizontal bottom velocity and waves, as well as the seabed roughness. A detailed description of this term is given in appendix 2 . Heat and salinity fluxes are considered to be zero at this boundary. The flux of turbulent kinetic energy is parameterised similarly as the one at the surface boundary.

At open lateral boundaries, the free-surface elevation $(\eta)$ and the component of transport orthogonal to the boundary $(U)$ are given by the radiation condition of Oey and Chen (1992): $U=U_{0} \pm(g H)^{1 / 2}\left(\eta-\eta_{0}\right)$. Others variables are given by $\nabla_{H} \varphi=\nabla_{H} \varphi_{0}$, where $\varphi$ stands for the tangential component of the depth averaged current and baroclinic velocities. $U_{0}, \varphi_{0}$ and $\eta_{0}$ refer to the large scale field forcing. Concerning temperature and salinity, an upstream condition implies that large-scale fields, $\mathrm{T}_{0}(\mathrm{t})$ and $\mathrm{S}_{0}(\mathrm{t})$, are advected into the simulated domain under inflow conditions. The large-scale fields are also applied over the whole grid at $\mathrm{t}=\mathrm{t}_{0}$ (initialisation). This initial state aims to start the simulation with the large-scale geostrophic circulation of the Gulf of Lion, generally identified as the Northern Current. The model is initialised with a fully established along slope circulation adjusted to bathymetry constraints, based on a linearised derivation of the external mode equations of the model (Estournel et al., 2003). 
The regional model was initialized and forced every day by the large scale Ocean General Circulation Model (OGCM) MOM outputs. Wave characteristics over the domain were described by the 6-hour outputs of the Vagmed waves-forecast model of Météo-France.

Concerning the buoyancy inputs, the freshwater inputs for the main rivers of the Gulf of Lion (GrandRhone, Petit-Rhone, Vidourle, Lez, Herault, Orb, Aude, Agly, Têt, Tech) (see Fig. 1a), are taken into account. Daily discharges provided by the 'Compagnie Nationale du Rhône' and by the 'Banque Hydro-MEDD/DE' were specified at the ten river mouths. The temperature in all rivers is set following measurements in Rhone river (Poirel et al., 2001), with a maximum value of $22{ }^{\circ} \mathrm{C}$ in October and a minimum value of $7^{\circ} \mathrm{C}$ in January and February.

\subsection{Sediment transport model}

The suspended sediment transport model aims at simulating the dispersal of the sedimentary particles resuspended by waves and currents, as well as bottom trawls. This model is governed by an advection-diffusion dispersion equation, and considered different particle grain sizes (see appendix 1). Deposition and erosion terms are incorporated into the seabed boundary condition. The erosion term was estimated with sediment dynamic models specific to each resuspension mechanisms (waves and current, trawl); they are described in the following chapters and in appendix 2.

Given that the Gulf of Lion sediments cover a wide range of size (Fig. 1b), primary (individual) particles in the sediment were clustered in 7 size classes ranging from clay to coarse sand, according to the Wentworth classification (1922). Two additional classes were considered for suspended particles to take into account aggregated particles. The aggregates characteristics were inferred from comparisons between in situ and laboratory particle size distribution of resuspended sediment (Durrieu de Madron et al., 2005). These measurements suggested that about $3 / 4$ of the clays and $1 / 4$ of the fine silts are incorporated into aggregates whereas the rest remains as primary particles. We considered that clays and fine silts contributed equally to the formation of both classes of aggregates. The characteristics of each class (median grain size, settling velocity and density) are indicated in the Table 1.

River sediment inputs were computed using water discharge (Q) and suspended sediment concentration estimates $(S S C=f(Q))$ established by different authors: Sempéré et al. (2000) for the Rhône River, Petelet-Giraud et al. (2003) for the Herault River, Serrat (1999) for the Agly River, and Serrat et al. (2001) for the Têt River. In absence of information for Orb and Aude Rivers, we used the relationship of the nearby Herault River. Finally, solid discharge of the Rhône River was divided into two parts: $90 \%$ for the Grand-Rhône branch and 10\% for the Petit-Rhône branch. Grain size distribution of river inputs was defined according to recent data collected in the Rhône River (Radakovitch, personal communication) and Têt River (Garcia-Esteves, 2005). All "small" rivers (Hérault, Agly, Orb, Aude, Vidourle and Tech) are considered to have the same grain distribution than 
the Têt River. Most of the suspended particles are silts (ca $80 \%$ for the Rhône River and $69 \%$ for the Têt River) and clays ( 18\% for the Rhône River and 24\% for the Têt River).

The grain size distribution of the shelf surface sediments was determined from the compilation of several sedimentological surveys that provided about 160 cores over the whole shelf. Figure $1 \mathrm{~b}$ shows the median grain size of the first centimetres of the sediment. Maps of the fraction of the different size classes were used at the initial time. Their characteristics slightly changed throughout the simulation according to the dispersal of river inputs, and the erosion and deposition of the different classes of sediment.

\subsection{Sediment dynamics for waves and currents}

The sediment erodability is controlled by the shear stress intensity and the bottom sediment properties (coarse non-cohesive vs. fine cohesive sediments). The limit between cohesive and non-cohesive sediment was fixed at $10 \%$ of clay $(<2 \mu \mathrm{m})$, which is in the range (3-14\%) defined in various studies (Dyer, 1986; Torfs, 1995; Panagiopoulos et al., 1997; Houwing, 2000). The Partheniades' law (1962) was used to compute the erosion flux of cohesive sediments, whereas the reference concentration based on the method of Zyserman and Fredsøe (1994) was used for the erosion flux of the noncohesive sediments (see appendix 2).

The stress values were computed using combined wave and currents conditions, and discriminated flat-bed and rippled bed conditions (see appendix 2). The bottom roughness calculation and ripples geometry for the non-cohesive sediments was based on the SEDTRANS96 model (Li and Amos, 1998; Li and Amos, 2001), which predicts the roughness and bedforms generated by a combined wave/current model. For cohesive and mixed sediments, the roughness scale model of Harris and Wiberg (2001) was used. Besides, bed armoring was implemented in the model to take into account the reduction of erosion flux of fine particles in mixed sediments, due to the protective effect of larger sand grains (Harris and Wiberg, 2001).

The critical shear stress (stress above which the sediment is likely to be removed) depends on grain size and sediment characteristics. For non-cohesive sediments, the critical shear stress is given in the form of a critical Shields parameter value, which depends on the grain size of each class (see appendix 2). For cohesive sediments, the threshold value is difficult to establish because it depends on the compaction and history of the sediment. Indeed, unconsolidated surface layer (fluff) is eroded for very weak shear stresses, ranging between 0.02 and $0.08 \mathrm{~N} \mathrm{~m}^{2}$ (El Ganaoui et al., 2004; Gust and Morris, 1989; Maa et al., 1998; Schaaff et al., 2002). The underlying, more consolidated layers, need larger critical shear stresses, between 0.1 and $0.61 \mathrm{~N} \mathrm{~m}^{2}$ (Maa et al., 1998; Houwing, 1999; Krishnappan and Marsalek, 2002, Palanques et al., 2002). In this study we considered an average critical shear stress of $0.2 \mathrm{~N} \mathrm{~m}^{2}$. 


\subsection{Resuspension by bottom trawls}

In absence of direct information of distribution and movement of trawler on the shelf, we used a probabilistic approach to simulate their position and trajectory. The daily schedule and number of active bottom trawlers was estimated from records of trawler fleet coming from different fishing ports (Fig. 3d). During working days, each trawler was assumed to perform 4 tows of 2 hours from 4 a.m. to 12 a.m.

A probabilistic distribution of fishing effort was simulated for both wind conditions, using several variables (depth, distance from the ports to the different fishing areas, and fishing rules in force in the area) (Fig. 2). The distribution map for each working day was selected according to the wind intensity next to the Sète port (major fishing port of the area) at 4 a.m. After being positioned randomly, each trawl was displaced using a random walk approach. Given the mesh size of the model ( $3 \mathrm{~km})$ and the trawling speed $\left(1.5 \mathrm{~m} \mathrm{~s}^{-1}\right)$, a crossing time of $33 \mathrm{~min}$ was considered before moving each trawler to one of the surrounding mesh. A maximum number of 3 trawlers per mesh was imposed.

The fluxes of sediment resuspended by otter bottom trawls and the characteristics of the sediment plumes were estimated by Durrieu de Madron et al. (2005). They showed that resuspension fluxes depend on the trawls groundrope gears, and above all on sediment texture (i.e., clay content) (see appendix 2). According to observations, resuspended sediment was distributed over the last $5 \mathrm{~m}$ above the seabed with a concentration inversely proportional to the seabed distance. For each time step $(180 \mathrm{~s})$, the resuspended mass of sediment is proportional to the trawled area: $4320 \mathrm{~m}^{2}$ considering a trawler speed of $1.5 \mathrm{~m} \mathrm{~s}^{-1}$, and a combined net and door width of $16 \mathrm{~m}$. Because this area is much smaller than that of the model's mesh $\left(9 \mathrm{~km}^{2}\right)$, the resuspended mass was spread over the entire mesh and within layers including the last $5 \mathrm{~m}$ above bottom. The bias introduced by the forced diffusion is likely to be small, since most of the resuspended sediment is rapidly deposited (within 1-2 hours according to Durrieu de Madron et al., 2005), and remains confined to the adjacent meshes.

\subsection{Scenarios and numerical solutions}

Four scenarios were carried out in order to answer the question about the role of resuspension in the shelf-slope exchanges of particulate matter. They considered the same hydrodynamic forcings described in chapter 3.1 .

- The first simulation, which only takes into account the river particulate inputs, (i.e. resuspension is absent), was used as reference for the shelf deposit and the export of riverine particulate matter for the study period;

- The second scenario considered, in addition to the preceding simulation, resuspension of sediment by currents and waves only; 
- $\quad$ The third scenario considered the sediment resu spension by trawls only;

- A fourth scenario combining resuspension by waves and currents, as well as trawls, checked if there is any significant non linear effect.

Simulations lasted 16 months from January 1, 1998 to April 1, 1999. The water column was clear of suspended particles at the initial time, and the system was gradually loaded in suspended particles, coming from rivers and/or sediment resuspension during the first months of simulations. As the residence time of shelf waters is about 2 months (Durrieu de Madron et al., 2003), we checked that the suspended sediment concentration (SSC) of the shelf water was stabilized on the third month (March 1998). For each scenario, annual budgets of resuspended sediment, deposited particles on the shelf, and exported particles to the slope, were calculated between April 1998 and April 1999.

Hydrology and circulation on the shelf and upper slope were measured for two surveys conducted in March/April 1998 and January 1999. Previous studies tested the ability of the hydrodynamical model to correctly reproduce the hydrology and the wind-induced circulation patterns observed in March/April 1998 (Estournel et al., 2003), and the formation of dense water on the shelf and its cascading over the slope in January/February 1999 (Dufau-Julliand et al., 2004). Critical but indefinite parameters of the sediment dynamics model (i.e., clay content threshold for cohesive/non-cohesive behaviour, erosion flux and critical shear stress for cohesive sediments) were adjusted to fit the in situ observations (47 casts) collected all over the shelf during these surveys (Fig. 1a). The agreement was quantified by computing the differences between simulated SSC values (combining both resuspension by waves and current conditions and trawling activity) within the last three levels above the bottom with observed near-bottom SSC, estimated from optical (light transmission) measurements. The adjusted parameters yielded differences in SSC less than 35\% for more than half of the stations and maximum differences of $80 \%$.

\section{RESULTS}

\section{Hydrodynamical conditions.}

During the simulation period (April 1998 - April 1999) the Rhône River supplied respectively $80 \%$ of the freshwater and $90 \%$ of the suspended sediment inputs to the Gulf (Fig. 3a). The annual total solid discharges amounted to $3.6 \times 10^{6} \mathrm{~T}$, that were supplied during medium floods occurring mostly during the spring 1998 and late autumn 1998-winter 1999 (Fig. 3b). Given that the average sediment discharge from the Rhône over the 1977-2004 period is about $10.1 \times 10^{6} \mathrm{Ty}^{-1}$ and peaks at more than $33 \times 10^{6} \mathrm{~T} \mathrm{y}^{-1}$ (Bourrin et al., 2007), the 1998-1999 period appears as a low discharge year.

E-SE gales were rare and brief but caused locally strong precipitations and sudden floods. N-NE continental winds were predominant throughout the year (Fig. 3c). These cold and dry winds affected the annual cycle of the shelf water thermal characteristics, by inducing strong mixing and cooling 
during fall and winter. As the average salinity of the shelf water was rather constant all over the year, decreasing temperature induced a progressive increase of density that culminated in late winter (Fig. 3f). During winter and early spring, large quantities of dense shelf water overflowed the shelf break and cascaded down the slope (Fig. 3g), especially in February/March 1999. Export of water mainly occurred in the western part of the shelf, and was compensated by an inflow in the eastern part of the Gulf. Béthoux et al. (2002) showed that an event of such intensity had not occurred since 1993, and that the last event probably went back to the winters 1987-1988. An event of similar intensity was observed in winter 2005 (Canals et al., 2006).

Bottom stress presents a seasonal cycle with larger values between the end of autumn and the beginning of spring (Fig. 3e), due to the increase of the current intensity and wave conditions, and also to the weak stratification of the water column. Wind intensity and direction variability induced many bursts in the bottom stress, which was generally more intense on the western part of the shelf.

In summary, the study period was characterized by low river discharges and moderate wave conditions (with few E-SE storms), but by intense winter shelf water export through dense water cascading caused by sustained N-NW winds.

\section{Fate of river inputs without resuspension.}

Formatted: Bullets and Numbering

A first simulation was carried out by taking into account the sediment supplied by rivers only, in order to estimate the direct contribution of rivers to the sediment export (Fig. 4). During the April 1998 - April 1999 period $3.6 \times 10^{6} \mathrm{~T}$ of sediment were discharge by rivers (Table 2). As previously mentioned, most of inputs derived from the Rhône River. Deposits of river sediment on the shelf, which amount to $3.1 \times 10^{6} \mathrm{~T}$, clearly reflect the difference in river discharges (Fig. 3a). Sediments supplied by the Hérault, Orb, and Aude Rivers in the northwestern part of the Gulf remained primarily confined to the inner shelf. Deposit of the Rhône River inputs formed a wedge extending over the eastern part of the shelf and the outer shelf as far as the southwestern end of the Gulf. The net deposit thickness was largest near the major river mouth, and was about $0.1 \mathrm{~mm}$ on most of the shelf. The grain size distribution reflected the accumulation gradient, with an early settling of the coarser particles on the prodeltas, and a fining texture along the transport pathways. Sediments in suspension exported from the shelf were mainly composed of fine particles. The exported quantity was $0.4 \times 10^{6} \mathrm{~T}$ (only $11 \%$ of river inputs (Table 2) and occurred for the two thirds during wintertime (Dec. 1998 - Apr. 1999). 
currents appeared as short events, with a maximum duration of a few days, throughout the year. Some larger and longer resuspension events were to be noted in spring and fall 1998, and also during December 1998 and February 1999, due to the action of stronger coastal currents or swells. During the April 1998 - April 1999 period about $35.3 \times 10^{9} \mathrm{~T}$ of sediment were resuspended (Table 2), preferentially on the inner shelf (water depth $<50 \mathrm{~m}$ (Fig. 6), and the largest part was composed of coarse sediments that quickly settled. The annual net erosion/deposition budget amounted to $9.2 \times 10^{6} \mathrm{~T}($ Table 2$)$, which was more than twice the annual river inputs.

Off-shelf export occurred as bursts, which immediately followed the resuspension events. They were generally of short duration except for a sustained period in February and March 1999 due to dense shelf water cascading (Fig. 5b and 13). Water flux at the shelf break (Fig. 3g) indicated that the two summer pulses on mid-June and mid-September 1998 occurred on the eastern part of the Gulf, while that all the other episodes occurred in its western part. The annual export of sediment solely resuspended by waves and currents amounted to $8.5 \times 10^{6} \mathrm{~T}$ (Fig. 13), which represented about $0.02 \%$ of the resuspended quantity (Table 2). The exported sediment was mostly composed of clays and fine silts, but the strong cascading-driven currents induced an export of larger particles (including sands) during the winter 1999.

The map of erosion and deposition regions at the end of the annual cycle (Fig. 6) indicated a net deposit over most of the shelf, except within the coastal band shallower than $30 \mathrm{~m}$, and also on the southwestern outer shelf. Resuspension by waves and currents induced a total redistribution of the riverine sediments, but did not significantly change the initial grain size distribution of the shelf sediments (i.e., cross-shelf gradient with coarser sediment near the coast and finer sediment seaward). Regions of stronger deposit were localised along a band between 30 and $70 \mathrm{~m}$ deep, extending from the Rhône River as far as Cape of Creus, which constitutes a natural outlet at the southwestern end of the Gulf. This band, which mimics the mid-shelf mud belt, was primarily composed of fine particles. Erosion of sediment by waves and currents was observed in the head of the westernmost canyons during the winter cascading period.

The dispersal of suspended sediment on the slope was variable according to the period of the year. From May to November, while the water column was stratified, the export of shelf suspended sediment was primarily restricted to the surface slope waters (Fig. 7a). The seaward dispersal in the upper layer $(0-500 \mathrm{~m})$ was limited by the core of the permanent cyclonic Northern Current that swept, along the slope, the material escaping from the shelf. From December to April, whilst the water column was weakly stratified or even unstable during the dense water cascading period, shelf suspended sediment rapidly spread into intermediate (500-1000 m) or deep (> $1000 \mathrm{~m}$ ) slope waters (Fig. 7b).

Resuspension and off-shelf sediment export induced by trawls - Conversely to the natural resuspension which occurs as irregular and short episodes, bottom trawling activity is periodic and rather constant over the whole year (Fig. 3d). Resuspension by trawls is dependant on the trawl number and positions. During the April 1998 - April 1999 period, bottom trawlers worked 250 days and 
the fishing fleet had a daily mean strength of 63 boats. The total surface scraped by trawlers during this annual period amounted to $11,000 \mathrm{~km}^{2}$, which is comparable to the surface of the Gulf of Lion shelf (ca 12,000 $\mathrm{km}^{2}$ ). Some regions were trawled several times a year, whereas others were untouched. For strong winds (> $10 \mathrm{~m} \mathrm{~s}^{-1}$ ), trawlers were mostly confined to the coastal area, where coarse sediment is more abundant (Fig. 2a). Days of strong winds were present $13 \%$ of the year, most of the time in autumn and winter. During low wind periods $\left(\leq 10 \mathrm{~m} \mathrm{~s}^{-1}\right)$, trawlers preferentially worked on the outer shelf and eroded finer sediment (Fig. 2b). About $2.2 \times 10^{4} \mathrm{~T}$ of sediment were resuspended daily by bottom trawls (Fig. 8a), with a maximum between September and December 1998 when trawlers were more numerous (> 80, Fig. 3d). The annual mass of sediment resuspended by trawling amounted to $5.6 \times 10^{6} \mathrm{~T}$ (Table 2), most of it originating from depths between 80 and $130 \mathrm{~m}$ (Fig. 9). Considering the fraction that settled shortly after resuspension, the annual net erosion/deposition budget on the shelf amounted to $0.4 \times 10^{6} \mathrm{~T}$ (Table 2), which was one order of magnitude less than that induced by waves- and current-induced resuspension.

The export of resuspended sediment from the shelf showed a seasonal variability, with minimum fluxes during summertime (whilst the resuspension on shelf was maximum), and a significant increase arising from transport pulses during the winter and spring periods. The fine-grained sediment resuspended by trawlers on the outer shelf was exported primarily in the western half of the Gulf (Fig. 9). The off-shelf export added up to $0.4 \times 10^{6} \mathrm{~T}$ annually, which accounted for $\sim 7 \%$ of the quantity of sediment resuspended by trawling on the shelf (Table 2 and Fig. 13).

Transects showed that the cross-slope dispersal of the fine-grained sediment resuspended by trawlers went deeper than for the sediment resuspended by waves and currents, due probably to the proximity of regions of intense trawling activity with the shelf edge. Some sediment reached by settling depths of 1500-2000 m during summer stratified condition (Fig. 10a). Cascading of dense water during winter caused a rapid advection of turbid shelf water down to $1000 \mathrm{~m} \mathrm{deep}$, and settling favoured the spreading of suspended sediment as far as $2000 \mathrm{~m}$ deep (Fig. 10b). Above the bottom layer, the dispersal of the suspended particles present in intermediate and deep waters were advected toward the southwest by the general along slope circulation.

Resuspension and off-shelf sediment export induced by both waves/currents and trawls - A simulation with both natural (waves and currents) and anthopogenic (trawling) processes was intended to check if our assumption about the independence on sediment transport was justifiable. By comparison with the sum of both processes, the annual resuspension and deposition on the shelf due to the combined effect of waves/currents and trawls decrease by $\sim 0.17 \%$, and the off-shelf export did not change (Table 2).

The resulting impact of both resuspension processes in the annual change in sediment level is depicted figure 12. By comparison with the impact of each individual resuspension process (Fig. 6 and 9), the net erosion/deposition intensity is smoothed all over the shelf. The major areas of net erosion 
appeared along the coast, on the western outer shelf and around Cape de Creus at the southwestern end of the Gulf. Net sediment accumulation took place over most in the middle shelf and eastern shelf, especially between 20 and 50 m deep.

The interaction between the two resuspension processes likely relates to the sediment redistribution on the shelf and to the (simple and irreversible) aggregation mechanism used in the model. Trawlinginduced resuspension produces over time a progressive coarsening of the fishing grounds sediments, and a subsequent decrease of the resuspension and deposition fluxes. However, decrease of the deposition flux is slightly lower than that of resuspension because the larger fraction of suspended flocs, build-up from fine (clay and fine silts) sediments, has a higher settling velocity than individual particles and enhances the deposition flux. The impact of bottom trawling activity on the sediment grain size has been already observed. Brown et al. (2005) showed on the southeastern Bering Sea that an area protected from bottom trawling, but submitted as the entire coastal region area to natural resuspension, had a significantly finer grain size owing to the lack of winnowing impact of trawlinginduced resuspension. Thus some synergist effects between natural and trawling resuspensions exist, but they do only change weakly the net erosion and export fluxes for the Gulf of Lion.

\section{DISCUSSION}

\section{Comparison of sediment resuspension by waves/currents and trawls}

On average, the amount of sediment resuspended by waves and currents exceeds by 3 to 4 orders of magnitude those induced by trawling (Table 2). By calculating the suspended mass per bottom eroded area for annual and winter/summer periods, a comparison can be made between depths eroded by waves and currents, and by trawls (Fig. 11).

Wave and current resuspension flux strongly decreases with increasing water depth, because of the decreasing impact of wave motions, and stabilizes on the outer shelf where strong bottom currents still resuspend muddy sediments (Fig. 11a). Seasonal (winter and summer) fluxes in shallow water are comparable, but summer fluxes decrease more rapidly offshore due to the weaker bottom currents intensity.

Resuspension fluxes induced by trawling are maximum on the outer shelf (between 80 and $130 \mathrm{~m}$ of depth) and culminate around $100 \mathrm{~m}$ depth (Fig. 11b). Seasonally, fluxes are weaker during the winter period by a factor of about 2 , because bad sea conditions reduce the average number of sea trips (Fig. 3d). On a yearly basis, resuspension fluxes generated by trawls on the outer shelf are lower than the fluxes generated at the same depths by waves and currents. However, the trawling-induced fluxes significantly exceed the waves and currant-induced fluxes during summertime. 
Churchill et al. (1989) suggested, using a simple model, that wave and current on the mid-Atlantic Bight were responsible for the resuspension on the inner shelf shallow water, whereas trawling was the principal cause of resuspension on the outer shelf. Our study shows comparable results and emphasizes the significant impact of bottom trawling on sediment remobilisation in deep regions of continental shelves. However, notable differences appear concerning the intensity of the resuspension fluxes. Indeed, the range of resuspension fluxes by the waves and current $\left(0-0.02 \mathrm{~kg} \mathrm{~m}^{-2}\right)$ or trawling $\left(0-0.01 \mathrm{~kg} \mathrm{~m}^{-2}\right)$ in the Churchill et al. study (1989) is 1 to 3 orders of magnitude weaker than those estimated at similar depths for the Gulf of Lion. Though these fluxes were calculated for different periods (3 months in Churchill et al. study (1989), 12 months in our study), the large discrepancy very likely results from different seafloor characteristics, as the Gulf of Lion shelf is mainly made up of fine sediments (clays and silts), whereas sands primarily dominate the seafloor of the Mid-Atlantic Bight.

Impact on sedimentary budget

The main export pathways differ for naturally or trawling-induced resuspended sediments because of the different resuspension regions. Waves and currents resuspend sediment mostly on the inner shelf, where it is composed of coarser grains that quickly settle. The fine fraction is then primarily transported along shore toward the southwestern end of the Gulf where it escapes the shelf. Conversely, fine sediment resuspended by trawls is mostly exported to the central slope, owing to the fact that trawled regions are mainly located on the outer shelf, close to the shelf break.

Whereas resuspension induced by waves and currents usually dwarfs that induced by trawling, the net erosion (i.e., resuspension-deposition) and the export are more comparable (Table 2). Indeed, sediments resuspended by trawls contribute to about $5 \%$ of the annual total export of riverborne and resuspended sediment Gulf of Lion shelf (Table 2 and Fig. 13). Nevertheless, this export shows an important seasonal and interannual variability due to the storm frequency and intensity, resulting in a variable contribution of trawling to the export.

During summertime the effect of waves and currents is minimal while the activity of trawling is maximum. Quantitatively, these conditions induce an increased contribution of the trawling impact, which reaches $7 \%$ of the total export for the period April 98-September 98. During wintertime the contribution of trawling is minimum around $4 \%$.

Ulses et al. (submitted) estimated - using a similar modelling approach - a sediment resuspension and export by waves and currents for the Gulf of Lion for the November 2003 - May 2004 period. This latter period was characterized by large river discharges and E-SE storm activity, with the occurrence of one major flood and two extreme storms, but mild dense water formation and export. It was quite different from the low river discharges, low E-SE storm activity, but massive dense shelf water cascading 1998-1999 winter period addressed in the present study. The amount of sediment exported during comparable time period reveals that the export during the November 2003 and March 2004 period $\left(8.6 \times 10^{6} \mathrm{~T}\right)$ was larger than during the $1998-1999$ period $\left(5.7 \times 10^{6} \mathrm{~T}\right.$ between November $1998-$ March 1999). These two periods were very energetic and are believed to represent the upper range of 
the export. On the other side, Durrieu de Madron et al. (2000) estimated from a box model budgeting approach based on direct mea surements performed during two seasonal surveys, an annual export of suspended particulate matter of about $1.9 \times 10^{6} \mathrm{~T}$. This crude estimate is believed to represent the lower range of the export, as surveys were performed in 1995-1996 during relatively calm conditions. Assuming that the export of sediment associated to the trawling activity is relatively constant from one year to the other (i.e., of the order of $0.4 \times 10^{6} \mathrm{~T}$ ), we estimated that this activity could contribute between few and 20 percents of the annual exchange of suspended sediment at the scale of the Gulf.

\section{SUMMARY}

Resuspension and transport of sediment in the Gulf of Lion, due to waves and currents on one hand, and to trawling on the other hand, have been modelled for an annual period (April 1998 - April 1999). The major conclusions that can be drawn with these results are:

- Natural resuspension by waves and currents occurred during short episodes mostly during fall and winter. It was concentrated on the inner-shelf due to wave action, but also on the southwestern outer shelf due to the strong bottom currents occurring during wintertime. Trawling-induced resuspension occurred regularly throughout the year. It was concentrated on the outer shelf, with a maximum intensity around $90 \mathrm{~m}$ depth. Trawling-induced resuspension fluxes are on average several orders of magnitude lower than the waves and currents-induced resuspension fluxes. Nevertheless, they are maximum and locally predominant during summertime when the wave and currents activity is lowest.

- The total annual off-shelf export of sediment by waves and currents were one order of magnitude larger than the export linked to trawling. Export concerned the finest fraction of the sediment (clays and fine silts) and took place primarily in the southwestern end of the Gulf for the sediment resuspended by waves and currents and the central shelf for the sediment resuspended by trawling. During energetic years (i.e., with large flood, strong marine storm or dense water formation), the trawling activity contributed little (few percents) to the total shelf export of fine sediment. However, trawling was thought to contribute significantly (up to $20 \%$ of the export) during calm years.

- No significant interferences between both resuspension processes were estimated in term of resuspension/deposition and export fluxes.

\section{ACKNOWLEDGMENTS}

The authors acknowledge the support from the European Commission (INTERPOL project under contract EVK3-2000-00023 and EUROSTRATAFORM project under contract EVK3-CT-2002-00079). 


\section{REFERENCES}

Agrawal, Y.C., Pottsmith, H.C. 2000. Instruments for particle size and settling velocity observations in sediment tran sport. Marine Geology, 168, 89-114

Amos, C.L., Daborn, G.R., Christian H.A. 1992 In situ erosion measurements on fine-grained sediments from the Bay of Fundy. Marine Geology, 108, 175-196.

Amos, C.L., Feeney, T., Sutherland, T.F., Luternauer, J.L. 1997. The stability of fine grained sediments from the Fraser River delta. Estuarine, Coastal and Shelf Science, 45, 507-524.

Arakawa, A. \& Suarez, M.J. 1983. Vertical differencing of the primitive equations in sigma coordinates, Monthly Weather Review, 111, 34-45.

Auclair, F., Marsaleix, P., Estournel C., 2000. Sigma coordinate pressure gradient errors : Evaluation and reduction by an inverse method. Journal of Atmospheric and Oceanic Technologies, 17, 13471367.

Béthoux, J.P., Durrieu de Madron, X., Nyffeler, F, Tailliez, D. 2002. Deep water in the western Mediterranean : peculiar 1999 and 2000 characteristics, shelf formation hypothesis, variability since 1970 and geochemical inferences. Journal of Marine Systems, 33-34, 117-131.

Black, K.S. 1997. Microbiogical factors contributing to erosion resistance in natural cohesive sediments. In: Burst, N., Parker, R. and Watts, J., Editors. Cohesive sediments, John Wiley \& Sons Ltd, Chichester, pp. 231-244.

Blumberg, A.F., Mellor, G., 1987. A description of a three dimensional coastal circulation model, In : Three Dimensional Coastal Ocean Model, edited by N. Heaps, 208 pp.

Bougeault, P., Lacarrere, P. 1989. Parameterisation of orography-induced turbulence in a meso-beta scale model, Monthly Weather Review, 117, pp. 1872-1890.

Bourrin, F., Durrieu de Madron, X., Ludwig, W., 2007. Contribution to the study of coastal rivers and associated prodeltas to sediment supply in Gulf of Lions (N-W Mediterranean Sea). Vie et Milieu. Life and Environment. In press.

Brown E.J., Finney, B., Dommisse, M. Hills, S. 2005. Effects of commercial otter trawling on the physical environment of the southeastern Bering Sea. Continental Shelf Research, 25, 1281-1301.

Canals, M., Puig, P., Durrieu de Madron, X., Heussner, S., Palanques, A., Fabrè J. 2006. Flushing submarine cany ons. Nature, 444, 354-357.

Churchill, J.H. 1989. The effect of commercial trawling on sediment resuspension and transport over the Middle Atlantic Bight continental shelf. Continental Shelf Research, 9, 841-864.

DeAlteris, J., L. Skrobe and C. Lipsky. 1999. The significance of seabed disturbance by mobile fishing gear relative to natural processes: a case study in Narragansett Bay, Rhode Island. In L. R. Benaka, editor. Fish Habitat: Essential fish habitat and rehabilitation. American Fisheries Society, Symposium 22, Bethesda, Maryland, 224-237

Dufau-Julliand, C., Marsaleix, P., Petrenko, A., Dekeyser, I. 2004. 3D modeling of the Gulf of Lion's hydrodynamics (NW Med.) during January 1999 (MOOGLI3 experiment) and late winter 1999: WIW formation and cascading over the shelf break. Journal of Geophysical Research.109, C11002, doi:10.1029/203JC002019.

Durrieu de Madron, X., Nyffeler, F., Godet, C.H. 1990. Hydrographic structure and nepheloïd spatial distribution in the Gulf of Lions continental margin. Continental Shelf Research, 10, 915-929.

Durrieu de Madron, X., Abassi, A., Heussner, S., Monaco, A., Aloisi, J.C., Radakovitch, O., Giresse, P., Buscail, R., Kerhervé, P. 2000. Particulate matter and organic carbon budgets for the Gulf of Lions (NW Mediterranean). Oceanologica Acta, 23 (6), 717-730

Durrieu de Madron, X., Denis, L., Diaz, F., Garcia, N., Guieu, C., Grenz, C., Loÿe-Pilot, M.D., Ludwig, W., Moutin, T., Raimbault, P., Ridame, C. 2003. Nutrients and carbon budgets for the Gulf of Lion during the Moogli cruises. Oceanologica Acta, 26, 421-433. 
Durrieu de Madron X., Ferré, B., Le Corre, G., Grenz, C., Conan, P., Pujo-Pay, M., Bodiot, O., Buscail, R. (2005) Trawling-induced resuspension and dispersal of muddy sediments and dissolved elements. Continental Shelf Research, 25 (19-20), 2387-2409.

Dyer, K.R. 1986. Coastal and Estuarine Sediment Dynamics, John Wiley and Sons, London.

El Ganaoui O., Schaaff E., Boyer P., Amielh M., Anselmet F. and Grenz C. (2004) The deposition and erosion of cohesive sediments determined by a multi-class model. Estuarine, Coastal and Shelf Science, 60 (3), 457-475

Estournel, C., Kondrachoff, V., Marsaleix, P., Vehil, R. 1997. The plume of the Rhône : numerical simulation and remote sensing, Continental Shelf Research, 17, 899-924.

Estournel, C., Broche, P., Marsaleix, P., Devenon, J.L., Auclair, F., Vehil, R. 2001. The Rhone river plume in unsteady conditions : numerical and experimental results. Estuarine, Coastal and Shelf Science, 53, 25-38.

Estournel, C., Durrieu de Madron, X., Marsaleix, P., Auclair, F., Julliand, C., Vehil, R. 2003. Observations and modelisation of the winter coastal oceanic circulation in the Gu lf of Lions under wind conditions influenced by the continental orography (FETCH experiment). Journal of Geophysical Research, 108(C3), p. 8059.

Ferré, B., Guizien, K., Durrieu de Madron, X., , Palanques, A., Guillén, J., Grémare, A. 2005.Fine sediment dynamics study during a winter storm in the Gulf of Lion shelf (NW Mediterranean), en révision à Continental Shelf Research. Continental Shelf Research, 25 (19-20), 2410-2427.

Garcia-Estevez, J. 2005. Transferts géochimiques en Méditerranée : exemple de la rivière Têt et de son bassin versant. Ph.D. Thesis, Uni versity of Perpignan, pp 263.

Geernaert, G.L. 1990. Bulk parameterizations for the wind stress and heat fluxes. In: Geenaert and Plant (Eds.), Surface waves and fluxes. Volume I -Current theory. Kluwer Academic Publishers, pp. 336.

Grant, W.D., Madsen, O.S., 1982. Movable bed roughness in unsteady oscillatory flow. Journal of Geophysical research, 87, 469-481.

Guillén J., Bourrin, F., Palanques, A., Durrieu de Madron, X., Puig, P., Buscail, R. 2006. Sediment dynamics during "wet" and "dry" storm events on the Têt inner shelf (SW Gulf of Lions). Marine Geology, 234, 129-142.

Gust, G., Morris, M.J. 1989. Erosion thresholds and entrainment rates of undisturbed in situ sediments. Journal Coastal Research, 5, 87-99.

Harris, C.K, Wiberg, P.L. 2001. A two-dimensional, time-dependent model of suspended sediment transport and bed reworking for continental shelves. Computers and Geosciences, (27), 675-690.

Heussner S., Durrieu de Madron, X., Calafat, A., Canals, M., Carbonne, J., Delsaut, N., Saragoni, G., 2006. Spatial and temporal variability of downward particle fluxes on a continental slope: lessons from an 8-yr experiment in the Gulf of Lions (NW Mediterranean). Marine Geology, 234, 63-92

Hill, P.S., Syvitski, J.P., Cowan, E.A., Powell, R.D., 1998. Insitu observations of floc settling velocities in Glacier Bay, Alaska. Marine Geology, 145, 85-94.

Houwing, E.J. 1999. Determination of the critical erosion threshold of cohesive sediments on intertidal mudflats along the Dutch Wadden sea coast. Estuarine, Coastal and Shelf Science, 49, 545-555.

Houwing, E.J. 2000. Sediment dynamics in the pioneer zone in the land reclamation area of the Wadden Sea, Groningen, The Netherlands. Ph.D. Thesis, University of Utrecht, Utrecht.

Krishnappan, B.G., Marsalek, J., 2002. Transport characteristics of fine sediment from an on-stream stormwater management pond. Urban Water, 4, pp. 3-11.

Lapouyade, A., Durrieu de Madron, X., 2001. Seasonal variablility of the advective transport of particulate matter and organic carbon in the Gulf of Lion (NW Mediterranean). Oceanologica Acta, 24, 295-312.

Li, M.Z., Amos, C.L. 1998. Predicting ripple geometry and bed roughness under combined waves and currents in a continental shelf environment. Continental Shelf Research, 18(9), 941-970. 
Li, M.Z., Amos, C.L. 2001. SEDTRANS96 : the upgraded and better calibrated sediment-transport model for continental shelves. Computers and Geosciences, (27), 619-645.

Maa, J.P., Sanford, L., Halka, J.P. 1998. Sediment resuspension characteristics in Baltimore Harbor, Maryland. Marine Geology, 146, 137-145

Marsaleix, P., Estournel, C., Kondrachoff, V., Vehil, R. 1998. A numerical study of the formation of the Rhone river plume. Journal of Marine Systems, 14, 99-115.

Meadows, P.S., Tait, J., Hussain, S.A. 1990. Effects of estuarine infauna on sediment stability and particle sedimentation. Hydrobiologia, 190, 263-266.

Millot, C., 1999. Circulation in the western Mediterranean Sea. Journal of Marine Systems, 20 (1-4), 423-442.

Monaco, A., Durrieu de Madron, X., Radakovitch, O., Heussner, S. \& Carbonne, J. 1999. Origin and variability of downward biogeochemical fluxes on the Rhône continental margin (NW Mediterranean). Deep-Sea Research I, 46, 1483-1511.

Mulder, H.P., Udink, C. 1991. Modelling of cohesive sediment transport. A case study: the western Scheldt estuary. In: Edge, B.L. Editor. Proceedings of the $22^{\text {nd }}$ International Conference on Coastal Engeneering, ASCE, 3012-3023.

Nielsen, P. 1986. Suspended sediment concentrations under waves. Coastal Engeneering, 10, 23-31?

Oey, L.Y., Chen, P. 1992. A model simulation of circulation in the northeast Atlantic shelves and seas. J. Geophys. Res., 97, 20,087-20,115

Palanques, A., Durrieu de Madron, X., Puig, P., Fabres, J., Guillén, J., Calafat A., Canals, M., Heussner, S., Bonnin, J. 2006. Suspended sediment fluxes and transport processes in the Gulf of Lions submarine canyons. The role of storms and dense water cascading. Marine Geology, 234, 4361.

Palanques, A., Puig, P., Guillén, J., Jiménez, J., Gracia, V., Sánchez-Arcilla, A. and Madsen, O. 2002. Near-bottom suspended sediment fluxes on the microtidal low-energy Ebro continental shelf (NW Mediterranean) Continental Shelf Research, 22, 285-303.

Panagiotopoulos, I., Voulgaris, G., Collins, M.B. 1997, The influence of clay on the threshold of movement on fine sandy beds, Coastal Engineering, 32, 19-43.

Partheniades, E. 1962. A study of erosion and deposition of cohesive soils in salt water. Ph. D. Thesis. University of California, Berkeley, $182 \mathrm{pp}$.

Pethelet-Giraud, E., Negrel, P.-H., Cubizolles, J., 2003. Flux exportés de l'Hérault vers la Méditerranée et origine des masses d'eau. Rapport BRGM /RP-52748-FR.

Petrenko, A., Leredde, Y., Marsaleix, P., 2004. Circulation in a stratified and wind-forced Gulf of Lions, NW Mediterranean Sea: in situ and modelling data. Continental Shelf Research, 25 (1), 7-27.

Poirel, A., Carrel, G., Olivier, J.M., 2001. Illustration de la complémentarité des chroniques environnementales dans l'étude d'un hydrosystème fluvial: régime thermique et peuplements piscicoles du Rhône, Workshop "Activities in the catchment area and water quality", Lyon Fleuves 2001, juin 2001.

Schaaff, E., Grenz, C., Pinazo, C., 2002. Erosion of particulate inorganic and organic matter in the Gulf of Lion. Comptes Rendus Géosciences, 334, 1071-1077.

Sempéré R., Charrière B., Van Wambeke F. and Cauwet G. (2000) Carbon inputs of the Rhone River to the Mediterranean Sea: Biogeochemical implications. Global Biogeochemical Cycles, 14, 669-681.

Serrat, P. 1999. Present sediment yield from a Mediterranean fluvial system: the Agly river (France). Comptes Rendus de I'Académie des Sciences - Series IIA - Earth and Planetary Science. 329,189196.

Serrat, P., Ludwig, W., Navarro, B., Blazi J.L., 2001. Spatial and temporal variability of sediment fluxes from a coastal Mediterranean river: the Têt (France). Comptes Rendus de l'Académie des Sciences Series IIA - Earth and Planetary Science, 333, 389-397. 
Soulsby, R.L., Hamm, L., Klopman, G., Myrhaug, D., Simons, R.R., Thomas G.P. 1993. Wave-current interaction within and outside the bottom boundary layer. Coastal Engeneering, 21, 41-69.

Soulsby, R.L., Whithouse, R.J.S.W. 1997. Threshold of sediment motion in coastal environments. Proceedins Pacific Coasts and Ports '97 Conference, Christchurch, 1, 149-154.

Torfs, H. 1995, Erosion of mud/sand mixtures. Ph.D. thesis, Katholieke Universiteit Leuven, faculteit der Toegepaste Wetenschappen, Departement Burgelijke Bouwkunde, Laboratorium voor Hydraulica.

Ulses, C., Estournel, C., Bonnin, J., Durrieu de Madron, X., Marsaleix, P. Impact of storms and dense water cascading on shelf-slope exchanges in the Gulf of Lion (NW Mediterranean). Journal of Geophysical Research (accepted).

Ulses, C., Estournel, C., Durrieu de Madron, X., Palanques, A. Suspended sediment transport in the Gulf of Lion (NW Mediterranean): Impact of extreme flood and storm. Continental Shelf Research (submitted)

Wentworth, C.K. 1922. A scale of grade and class terms for clastic sediments, Journal of Geology, 30, 377-392.

Wheatcroft, R.A. 1994. Temporal variation on bed configuration and one-dimensional bottom roughness at the mid-shelf STRESS site. Continental Shelf research, 14, 1167-1190.

Widdows, J., Brinsler, M.D., Bowley, N., Barrett C., 1998. A benthic annualar flume for in situ measurement of suspension feeding/biodeposition rates and erosion potential of intertidal cohesive sediments. Estuarine, Coastal and Shelf Sciences, 46, 27-38.1998

Zanke, U. 1977. Berechnung der Sinkgeschwindichkeiten von Sedimenten. Mitteilungen des FranziusInstitutes, 46, 231-245.

Zyserman, J.A., Fredsøe, J., 1994. Data analysis of bed concentration of suspended sediment. Journal of Hydraulic Engineering, ASCE, 120 (9), 1021-1041. 
The advection-diffusion equation is based on the mass conservation of the suspended sediment

$\frac{\partial C^{i}}{\partial t}+u \frac{\partial C^{i}}{\partial x}+v \frac{\partial C^{i}}{\partial y}+\left(w-W_{s}^{i}\right) \frac{\partial C^{i}}{\partial z}=K_{z} \frac{\partial^{2} C^{i}}{\partial z^{2}}$

where $C^{i}$ is the suspended sediment concentration (SSC) for the $i^{\text {th }}$ class of particles, $W_{s}^{i}$ is the settling coefficient.

The vertical turbulence was estimated using a turbulent closure scheme where the vertical diffusion coefficient $K_{z}$ is derived from the local Richardson number $\left(R i=-\frac{(g / \rho)(\partial \rho / \partial z)}{(\partial u / \partial z)^{2}}\right)$ :

$K_{z}=1.67 \times 10^{-3}\left(1+\frac{10}{3} R i\right)^{-3 / 2}$

where $\rho$ is the water density and $g$ is the gravitational acceleration equal to $9.81 \mathrm{~m}^{2} \mathrm{~s}^{-1}$.

Settling velocity $W_{s}^{i}$ (in $\mathrm{m} \mathrm{s}^{-1}$ ) for the particles with a diameter lower than $100 \mu \mathrm{m}$ was estimated as the 716 mean Stokes velocity of the individual size bins $D_{j}$ (in $\mathrm{m}$ ):

$W_{s}^{\prime}=\frac{\left(s_{i}-1\right) g D_{i}^{2}}{18 v}$

717 where $s_{i}$ is the relative grain density and $v$ is the kinematic water viscosity equal to $1.14 \times 10^{-6} \mathrm{~m}^{2} \mathrm{~s}^{-1}$.

718 Settling velocity for sand grain coarser than $100 \mu \mathrm{m}$ is computed using Zanke (1977) formula:

$W_{s}^{i}=\frac{10 v}{D_{i}}\left\{\left[1+\frac{0.01\left(s_{i}-1\right) g D_{i}^{3}}{v^{2}}\right]^{0.5}-1\right\}$ 


$$
W_{s}^{i}=0.45 \times 10^{-3}\left(D_{i} / 2\right)^{1.17}
$$

$$
\rho_{f}^{i}=\rho+\frac{18 \mu W_{s}}{g D_{f}^{2}}\left(1+\frac{3 C}{16} \operatorname{Re}\right)
$$

725 where $\rho_{f}^{i}$ is the aggregate density, $\mu$ is the dynamic water viscosity $\left(1.14 \times 10^{-3} \mathrm{~kg} \mathrm{~m}^{-1} \mathrm{~s}^{-2}\right), W_{s}$ is the 726 aggregate settling velocity, $D_{f}$ is the aggregate diameter, $C$ is the Carrier coefficient $(0.43)$ and $727 \quad \operatorname{Re}=\rho W_{s}^{i} D_{f}^{i} / \mu$ is the class $i$ Reynolds number. 


\section{Erosion fluxes}

730

Partheniades' law for cohesive sediments - It permits to calculate the erosion flux $F$ for each particle class $i$ according to the relation:

$$
F^{i}=p_{i} E_{0}^{i}\left(\frac{\tau_{\text {max }, s}}{\tau_{c r_{i}}}-1\right) \text { if } \tau_{\text {max }, s} \geq \tau_{c r_{i}}
$$

$$
F^{i}=p, W_{s}^{i} C\left(z_{1}\right) \rho_{s}^{i}
$$

739

where $C\left(z_{1}\right)$ is an adimensional concentration at the height $z_{1}$ corresponding to the first layer of the grid of above the seabed. Under combined wave and currents conditions, sediment is resuspended within the wave boundary layer and diffused in the water column by turbulence associated with the current (Soulsby et al., 1993). In the model, height of the first layer $\left(z_{1}\right)$ is variable and can be above the wave boundary layer of thickness $z_{w}$. The concentration $C\left(z_{1}\right)$ is thus calculated according to the reference concentration $C_{a}$, at height $z_{a}=2 D_{50}$, or the concentration at the boundary layer level $C\left(z_{w}\right)$.

$$
\begin{array}{ll}
C\left(z_{1}\right)=C_{a}\left(\frac{z_{1}}{z_{a}}\right)^{-b_{\max }} \text { for } z_{a} \leq z_{1} \leq z_{w} & \text { with } \quad b_{\max }=\frac{W_{s}}{K u_{w_{\max }}} \text { and } b_{\mathrm{m}}=\frac{W_{s}}{\kappa u_{s_{m}}} \\
C\left(z_{1}\right)=C\left(z_{w}\right)\left(\frac{z_{1}}{z_{w}}\right)^{-b_{m}} \text { for } z_{w}<z_{1} & z_{w}=\frac{u_{r_{\max }} T}{2 \pi}=\text { wave boundary thickness }
\end{array}
$$

$745 W_{s}$ is the sediment settling velocity, $\kappa$ is the von Karman constant $(=0.40), u_{* \max }=\left(\tau_{\max } / \rho\right)^{1 / 2}, u_{* m}=\left(\tau_{m}\right.$ $746(\rho)^{1 / 2}, \tau_{\max }$ is the maximum bed shear-stress in wave cycle, $\tau_{m}$ is the mean bed shear-stress in wave 747 cycle, and $T$ the wave period. 
748 The determination of the reference concentration is based on Zyserman and Fredsøe (1994) method,

749 and is calculated for a grain-related roughness height of $2.5 \times D_{50} / 30$ :

$$
C_{a}=\frac{0.331\left(\theta_{\max , s}-0.045\right)^{1.75}}{1+0.720\left(\theta_{\max , s}-0.045\right)^{1.75}}
$$

750 Where $\theta_{\operatorname{man} s}=\frac{\tau_{\max s}}{g\left(\rho_{s}-\rho\right) D_{30}}$ is the skin-friction Shields parameter.

The latter method is designed for flat-bed condition, so that $\tau_{\max }$ and $\tau_{m}$ are calculated using a grain related roughness height $\left(2.5 \times D_{\mathrm{so}} / 30\right)$. For a rippled bed, total-stress values should be used.

Erosion flux for trawl - The fluxes of sediment resuspended by bottom trawls were estimated by Durrieu de Madron et al. (2005). They showed that resuspension by trawl depend on the trawl's goundrope gear, but above all on the sediment texture (clay content). They inferred a linear relationship between the total resuspension flux, $E_{\mathrm{T}}$ in $\mathrm{kg} \mathrm{m}^{-2} \mathrm{~s}^{-1}$, and the clay fraction, $\mathrm{Fc}$ in \%:

$$
E_{r}=0.011 F_{C}+0.47 \quad\left(r^{2}=0.74\right)
$$

Total flux is then fractionated for the different sediment grain sizes, according to the fraction $p_{i}$ of class $i$.

$$
F^{i}=p_{l} E_{t}
$$

\section{Critical shear stress}

The critical shear stress is the shear stress from which sediment is likely to be removed. It depends on the grain itself and on bottom characteristics. This value is difficult to establish because it can vary from a factor 10 to 20 according to the type of resuspension considered.

For coarse non-cohesive sediments which mainly depend on grain characteristics, critical shear stress of each class $i$ is given in form of a critical Shields parameter value $\theta_{c r}^{i}$ which depends on adimensional grain size and results from experiments. Soulsby and Whithouse (1997) determined an algebraic equation nearest to the Shields curve:

$\theta_{c r}^{i}=\frac{0.30}{1+1.2 D_{*}^{i}}+0.055\left[1-e^{-0.020 D_{*}^{i}}\right]$ where $D_{*}^{i}=\left[\frac{g\left(s^{i}-1\right)}{v^{2}}\right]^{1 / 3} D_{50}^{i}$

\footnotetext{
Critical shear stress $\tau_{c r}^{i}$ is thus calculated with the equation
} 
$\theta_{\sigma}^{\prime}=\frac{\tau_{r}^{\prime}}{g\left(\rho_{s}^{\prime}-\rho\right) D_{s o}^{\prime}}$

770

$$
z_{0}=k / 30
$$

where $k$ is the total roughness height, and is the sum of three components: grain-related component

$\left(k_{g}\right)$, bedload component $\left(k_{t}\right)$, and form-drag component $\left(k_{f}\right)$ (Grant and Madsen, 1982).

$k=k_{\mathrm{g}}+k_{\ell}+k_{f}$

Grain roughness height is calculated using:

$k_{x}=2.5 \times D_{50}$

Bedload roughness is calculated using:

$k_{t}=522 \times D_{50}\left(\theta_{c w s}-\theta_{c r}\right)^{0.75}$

where $\theta_{c s}=\rho u_{c o s}^{2} /(\rho,-\rho) g D_{s w}$ is the Shields parameter related to the skin roughness, $\theta_{c r}$ is the critical Shields parameter which define grains remobilization, and $U_{*^{*} \text { ns }}$ is combined wave and currents shear velocities.

780 The ripple height and wavelength is then calculated according to Li and Amos (1998) (see below) to 781 obtain the form drag roughness height

782

$$
k_{f}=a_{r} \eta^{2} / \lambda
$$

where $a_{r}$ is a coefficient which varies according to authors. We choose 27.7, the most common value, 784 fixed by Grant and Madsen (1982).

785 The ripple height and wavelength depend on the characteristic and hydrodynamical conditions. Skin 786 shear velocities $\left(u_{\text {cws }}^{*}\right)$ and skin-friction combined wave and current Shields parameter $\left(\theta_{c w s}\right)$ are first 787 calculated using the grain roughness height $k_{g}$. The bedload roughness $k_{t}$ can thus be calculated, and 788 is used to obtain bedload shear velocities $\left(u^{*}{ }_{w t}, u_{c t}^{*}, u^{*}{ }_{c w t}\right)$. To calculate ripples dimension, the 789 combined-flow ripple predictor proposed by Li and Amos (1998), based on their filed observations of 790 


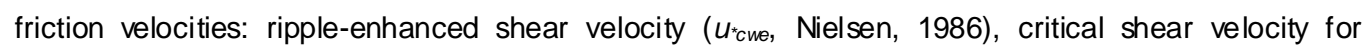
bedload transport $\left(u_{* r}\right)$, critical shear velocity for ripple break-off ( $u_{* b f}$, Grant and Madsen, 1982) and critical shear velocity for upper-plane bed sheet-flow $\left(u_{\text {*up }}\right)$. This last variable is given from a data compilation from preceding studies, carried out by Li and Amos (1998).

$u_{* \text { cwe }}=u_{* \text { cws }} /\left(1-\pi \eta_{p} / \lambda_{p}\right)$ where $\eta_{p}$ and $\lambda_{p}$ are respectively height and wavelength of pre-existing ripples.

$u_{\omega_{\sigma}}=\sqrt{\tau_{\sigma} / \rho}, \tau_{c r}$ being the critical shear stress for erosion as explain hereafter.

$u_{* b f}=1.34 S_{*}^{0.3} u_{* r}$ where $S_{*}=\left(D_{s 0} / 4 v\right)\left[\left(\rho_{x}-\rho\right) g D_{s 0} / \rho\right]$ is without dimension and $v$ is the cinematic seawater viscosity (equal to $1.14 \times 10^{-6}$ for a $15^{\circ} \mathrm{C}$ seawater).

$u_{s w p}=\sqrt{\tau_{w p} / \rho}$ where $\tau_{u p}=\theta_{u p}\left(\rho_{s}-\rho\right) g D_{50}$ and $\theta_{v p}=0.172 D_{s 0}^{-0 u s s}, D_{50}$ is expressed in mm.

The five limit conditions are presented above and permit to determine the adapted equations to calculate ripples height $\eta_{\text {rip }}$ and wavelength $\lambda_{\text {rip }}$ :

- If $u_{* \text { cwe }}<u_{*}$, there is no sediment transport and ripples have the same dimension as precedent time step.

- If $u_{*_{c w e}}>u_{*_{c r}}$ and $u_{*_{c w s}}<u_{*_{c}}$, the transport is local, weak, and close to ripples crest.

- $\quad \eta_{\text {rip }} / D_{50}=19.59\left(u *_{c w s} / u *_{c r}\right)+20.92$

- $\quad \eta_{\text {rip }} / \lambda_{\text {rip }}=0.12$

- If $u_{*_{c w s}}>u_{*_{c r}}$ and $u_{*_{c w t}}<u_{* b f}$, overall bedload transport will occur. case $n^{\circ} 1: u *_{c w} / u_{* s} \geq 1.25$, wave-dominant ripples

- If $u *_{b f} \leq u *_{c w t}<u *_{u p}$, break-off ripples will form

- If $u_{*_{c w t}} \geq u_{*_{u p}}$, ripples are washed out and upper-plane bed will be predicted. 
From these ripples height and wavelength values, the drag roughness, and then the total bottom roughness can be calculated, giving access to the calculation of the bottom shear stress which will determine the reference concentration.

For cohesive sediment, biological activity can have a considerable effect on bottom roughness. Microbial exudates can increase the critical shear stress, and presence of burrows in the sediment, due to bioturbation, can strengthen the seabed (Meadows et al., 1990; Black, 1997). Data concerning biological roughness being non-existent in the Gulf of Lion, ripples height and the wavelength for 3.6cohesive sediment are selected here equal to those measured on a silty site in the North-East of California, that says $0.6 \mathrm{~cm}$ and $10 \mathrm{~cm}$ respectively (Wheatcroft, 1994). The steepness of biogenic roughness elements is assumed to decay under high shear stresses as:

$\frac{\eta_{\text {bio }}}{\lambda_{\text {bio }}}=\exp \left(-1.67 \ln \theta_{w}-4.11\right)$ (Harris and Wiberg, 2001)

where $\theta_{w}=\tau_{*} / g(\rho,-\rho) D_{s 0}$.

For mixed sediment, an average between silty-bed and sandy-bed roughness scale is used, weighted by sand fraction of the bed (Harris et Wiberg, 2001) :

$\eta=\eta_{\text {rip }} f r_{s}+\eta_{\text {bio }}\left(1-f r_{s}\right)$
$\lambda=\lambda_{\text {rip }} f r_{s}+\lambda_{\text {bio }}\left(1-f r_{s}\right)$

where $f_{r s}$ is the sandy fraction. In the same way, total roughness is calculated by weighted average of the cohesive and non-cohesive contributions. A minimum value of $z_{0}=0.005 \mathrm{~cm}$ is specified so that roughness estimates do not become too small given the small-scale bed variations generally present on the sea floor.

\section{Bed armoring}

We used the method of Harris and Wiberg (2001), which considers several layers below an active layer available for erosion. Underlying layers are only available when active layer gets thinner by erosion or when shear stress increases. At the initial time, all layers (under-layers and active layer) have the same particle size distribution. The thickness and particle size distribution of each layer are updated at each time step according to deposit and erosion. Volume of each particles class per unit 
846 area of eroded seabed during a time step is limited by the quantity of sediment available in the active 847 layer.

848 The active layer of sandy bottom $\left(\delta^{i p}\right)$ is calculated according to the migration rate of the bottom $\left(Q_{b}\right)$

849 and the size of the ripples $\eta_{\text {rip }}$ and $\lambda_{\text {rip }}$ during a half wave-period:

$\delta^{r i p}=\frac{Q_{b} T}{2 C_{b} \lambda_{\text {rip }}}+6 D_{50}$
where $Q_{b}=\sum_{i}\left[f r_{i} \frac{25.3}{\left(\rho_{s}^{i}-\rho\right) g}\left(\tau_{c w s}-\tau_{c r}^{i}\right)^{1.5}\right]$ and $\tau_{c w s}=\rho u_{* c w s}^{2}$

where $f r_{i}$ is the fraction of class $i$ present in the sediment, $C_{b}$ is the concentration of the sediment (1porosity), and $6 D_{50}$ represents irregularities due to grains in order to prevent the active layer to disappear when no transport occurs.

For silty sediments, the active layer depth is supposed to be proportional to the shear stress at the bottom compared to the critical shear stresses $\tau_{\mathrm{cr}(50)}$ of the sediment.

$\delta^{s i l t}=0.006\left(\tau_{c w s}-\tau_{c r(50)}\right)+6 D_{50}$

For mixed sediment (mixture of silt and sand), the mixed layer $\delta_{\text {mix }}$ is calculated as a weighted mean of active layer depths for sandy and silty sediments.

$\delta_{m i x}=\delta^{r i p} f r_{s}+\delta^{s i l t}\left(1-f r_{s}\right)$

where $f r_{s}$ is the sand fraction of the bed. Volume of sediment available for erosion in a size class $i$ per

859 unit area of the bed is $f r_{i} C_{b} \delta_{\text {mix }}$. This volume is used to limit the erosion, taking into account initial 860 sediment characteristics (critical shear stress for erosion, grain density and particle size distribution). 861 Hence, when erosion exceeded the available sediment volume for each class $i$ at a given site, bed 862 armoring is applied by reducing the flux of this class. 


\section{FIGURES CAPTIONS}

Figure 1. (a) Topography of the Gulf of Lion in the model and position of hydrological stations. Dash lines delineate different domains used in the text. The line around shelf break depth $(200 \mathrm{~m})$ is the limit between the shelf and the open sea. The shelf is subdivided in two halves for water flux estimates given in Fig. 3g. (b) Median grain size of superficial sediment showing the seaward fining texture of the sediment and coarsening around the shelf edge.

Figure 2. Probability density distribution of bottom trawls for a) weak wind ( $\left.\leq 10 \mathrm{~m} \mathrm{~s}^{-1}\right)$ and b) strong winds $\left(>10 \mathrm{~m} \mathrm{~s}^{-1}\right)$. Black dots indicate the position of fishing ports sheltering the fleet of bottom trawlers: PV (Port-Vendres), PN (Port-la-Nouvelle), A (Agde), S (Sète), GR (Grau du Roi), PB (Port de Bouc). Isobaths 50, 200, 1000 and 2000 m superimposed as black lines.

Figure 3. Time series from April 1998 to April 1999 of (a) water discharges from the Rhône River and other rivers of the Gulf of Lion, (b) solid discharge from all rivers, (c) wind off Sète, (d) daily strength of bottom trawls in the Gulf of Lion, (e) bottom shear stress off Marseille and Banyuls (see Fig. 1 for position), (f) water density anomaly at $200 \mathrm{~m}$ depth at the eastern end (Planier Canyon) and southwestern end (Cap Creus Canyon) of the Gulf, and (g) and water flux across the shelf break (slope water import onto the shelf is positive, whereas shelf water export is negative).

Figure 4. Map of sediment thickness accumulated after a 16-month simulation (January 4, 1998 March, 31, 1999) taking solely into account sediment discharges from rivers (no resuspension allowed).

Figure 5. Annual (from April 1, 1998 to March 31, 1999) variability of the mass of sediment resuspended daily by waves and currents on the shelf (a) and exported towards the slope (b).

Figure 6. Map of sediment thickness accumulated or eroded between April 1, 1998 and March 31, 1999 taking into account sediment discharges from all rivers and resuspension by waves and currents. The contours are in $\mathrm{mm}$, positive values (light areas) represent deposition and negative values (dark areas) represent erosion.

Figure 7. Cross-margin sections on the western part of the Gulf of Lion (see Fig. 1 for section position) showing the distribution of suspended sediment concentration, resuspended by waves and currents, along with water density anomaly in (a) strongly stratified conditions (27 September 1998), and (b) weakly stratified conditions (24 February 1999). The contour unit is $\mathrm{mg} \mathrm{L}^{-1}$. The inserted map indicates the location of the cross-slope transect.

Figure 8. Annual (from April 1, 1998 to March 31, 1999) variability of the mass of sediment resuspended daily by bottom trawlers on the shelf (a) and exported towards the slope (b). 
Figure 9. Map of sediment thickness accumulated or eroded between April 1, 1998 and March 31, 1999 taking into account sediment discharges from all rivers and resuspension by bottom trawling. The contours are in $\mathrm{mm}$, positive values (light areas) represent deposition and negative values (dark areas) represent erosion.

Figure 10. Cross-margin sections on the western part of the Gulf of Lion (see Fig. 1 for section position) showing the distribution of sediment concentration, resuspended by bottom trawling, along with water density anomaly in (a) strongly stratified conditions (27 September 1998), and (b) weakly stratified conditions (24 February 1999). The contour unit is $\mathrm{mg} \mathrm{L}^{-1}$. The inserted map indicates the location of the cross-slope transect.

Figure 11. Map of sediment thickness accumulated or eroded between April 1, 1998 and March 31, 1999 taking into account sediment discharges from all rivers and both resuspension by waves and currents, and bottom trawling. The contours are in $\mathrm{mm}$, positive values (light areas) represent deposition and negative values (dark areas) represent erosion.

Figure 12. Annual and seasonal variation with depth of the resuspension fluxes on the Gulf of Lion's shelf linked (a) to natural (wave and current) activity, and (b) to bottom trawling activity. The first $30 \mathrm{~m}$ depths are not represented because of the strong erosion by waves and currents very near the coast which dwarfed the other values.

Figure 13. Cumulative export (in $10^{6}$ Tons) for the different scenarios: a) natural (waves and currents), b) trawls and c) mixed (waves, currents, and trawls). The dotted line indicates the sum of export for scenarios (a) and (b).

\section{TABLE CAPTIONS}

Table 1. Characteristics of particle grain size classes used in the sediment transport model.

Table 2. Annual sediment fluxes integrated between April 1, 1998 and March 31, 1999. Scenarios with natural (waves and currents) and/or trawling resuspension include sediment input by rivers. Deposition and export rates for these scenarios exclude the deposited and exported sediment directly deriving from rivers. Once riverine sediment has been deposited on the shelf it is accounted in the resuspension, and subsequent deposition and export fluxes. 
Table 1. Characteristics of particle grain size classes used in the sediment transport model

\begin{tabular}{|c|c|c|c|c|c|c|c|c|c|}
\hline Class & 1 & 2 & 3 & 4 & 5 & 6 & 7 & 8 & 9 \\
\hline category & clay & $\begin{array}{l}\text { Fine } \\
\text { silt }\end{array}$ & $\begin{array}{l}\text { Coarse } \\
\text { silt }\end{array}$ & $\begin{array}{l}\text { Very find } \\
\text { sand }\end{array}$ & $\begin{array}{l}\text { Fine } \\
\text { sand }\end{array}$ & $\begin{array}{c}\text { Median } \\
\text { sand }\end{array}$ & $\begin{array}{c}\text { Coarse } \\
\text { sand }\end{array}$ & \multicolumn{2}{|c|}{ Aggregates } \\
\hline $\begin{array}{c}D_{50} \\
(\mu \mathrm{m})\end{array}$ & 2.43 & 8.39 & 31.6 & 92.4 & 179.21 & 317 & 1063 & 31.6 & 129.5 \\
\hline $\begin{array}{c}W_{s} \\
\left(\mathrm{~m} \mathrm{~s}^{-1}\right)\end{array}$ & $4.6 \times 10^{-6}$ & $5.5 \times 10^{-5}$ & $7.7 \times 10^{-4}$ & $6.6 \times 10^{-3}$ & $2.0 \times 10^{-2}$ & $4.1 \times 10^{-2}$ & $1.6 \times 10^{-1}$ & $1.1 \times 10^{-4}$ & $5.9 \times 10^{-4}$ \\
\hline $\begin{array}{c}\rho \\
\left(\mathrm{kg} \mathrm{m}^{-3}\right)\end{array}$ & 2650 & 2650 & 2650 & 2650 & 2650 & 2650 & 2650 & 1264 & 1097 \\
\hline
\end{tabular}


Table 2. Annual sediment fluxes integrated between April 01, 1998 and March 31, 1999. Scenarios with Storms and/or Trawling resuspension include sediment input by rivers. Deposition rate for these scenarios excludes the deposited and exported sediment directly deriving from rivers. Once riverine sediment has been deposited on the shelf it is accounted in the resuspension, and subsequent deposition and export fluxes.

\begin{tabular}{|c|c|c|c|c|c|}
\hline Sed Fluxes & Rivers & Storms & Trawling & $\begin{array}{c}\text { Sum } \\
\text { (Storms + Trawling) }\end{array}$ & $\begin{array}{c}\text { Mixed } \\
\text { (Storms and Trawling) }\end{array}$ \\
\hline $\begin{array}{l}\text { River Discharge } \\
\qquad\left(10^{6} \mathrm{~T}^{-1}\right)\end{array}$ & 3.6 & 3.6 & 3.6 & 3.6 & 3.6 \\
\hline $\begin{array}{l}\text { Shelf Erosion } \\
\qquad\left(10^{6} \mathrm{Ty}^{-1}\right)\end{array}$ & 0 & 35264.6 & 5.6 & 35270.2 & 35209.4 \\
\hline $\begin{array}{l}\text { Shelf Deposition } \\
\qquad\left(10^{6} \mathrm{~T}^{-1}\right)\end{array}$ & 3.1 & 35255.4 & 5.2 & 35260.6 & 35200.1 \\
\hline $\begin{array}{c}\text { Shelf (Erosion- } \\
\text { Deposition) } \\
\left(10^{6} \mathrm{Ty}^{-1}\right)\end{array}$ & -3.1 & 9.2 & 0.4 & 9.6 & 9.3 \\
\hline $\begin{array}{l}\text { Shelf export } \\
\qquad\left(10^{6} \mathrm{~T}^{-1}\right)\end{array}$ & 0.4 & 8.5 & 0.4 & 8.9 & 8.9 \\
\hline
\end{tabular}


a)
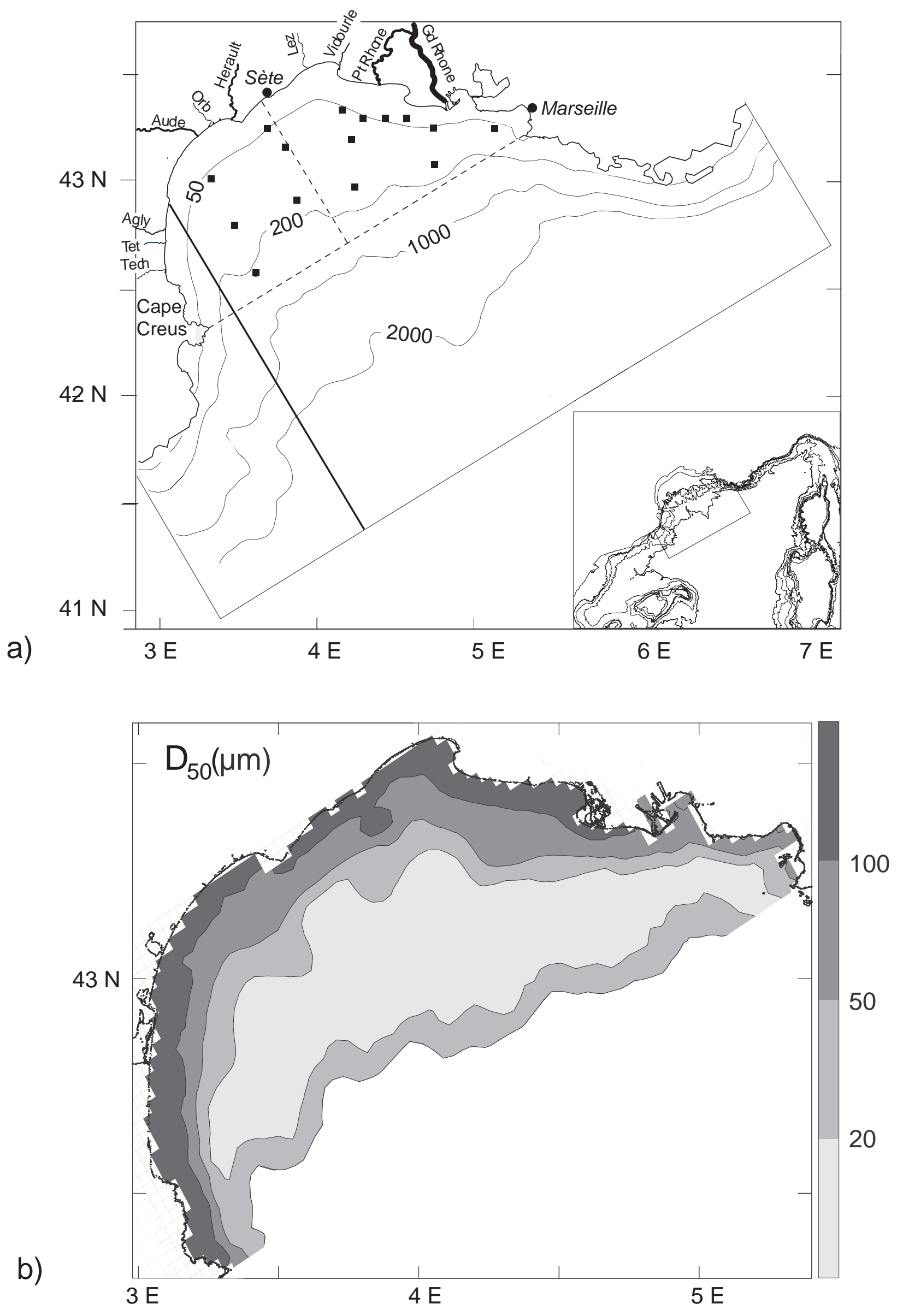

Ferre et al. Figure 1 

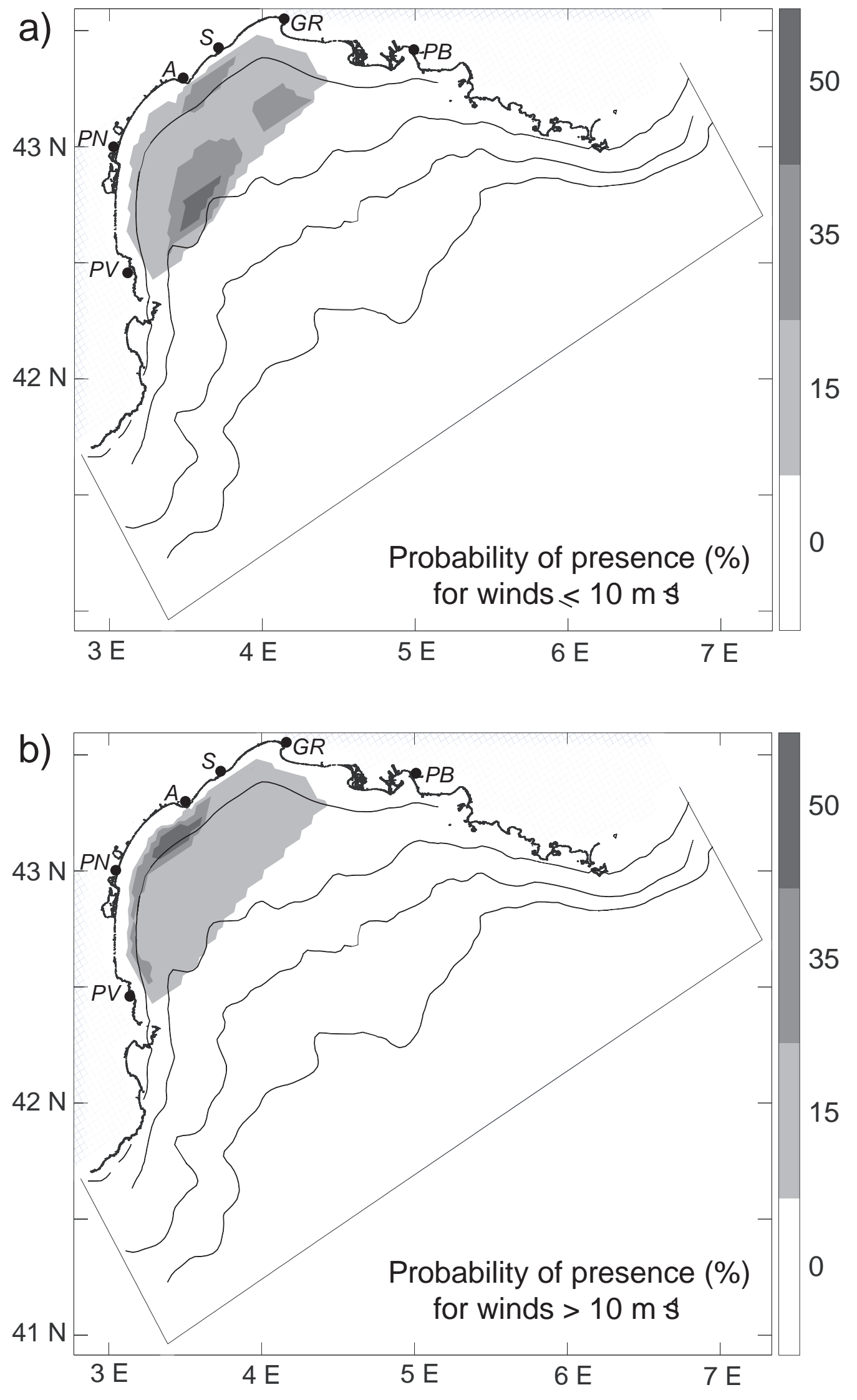

Ferre et al. Figure 2 


\section{Figure 3}

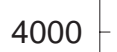

Rhone River

Other rivers

b) Rivers sediment discharge $\left(\mathrm{kg}^{-1}\right) \mathrm{s}$

20
15
10
5

0

c) Wind o Sete $\left(\mathrm{m} \mathrm{s}^{-1}\right)$

Tos
$\varepsilon$
ํ.

d) Trawl number

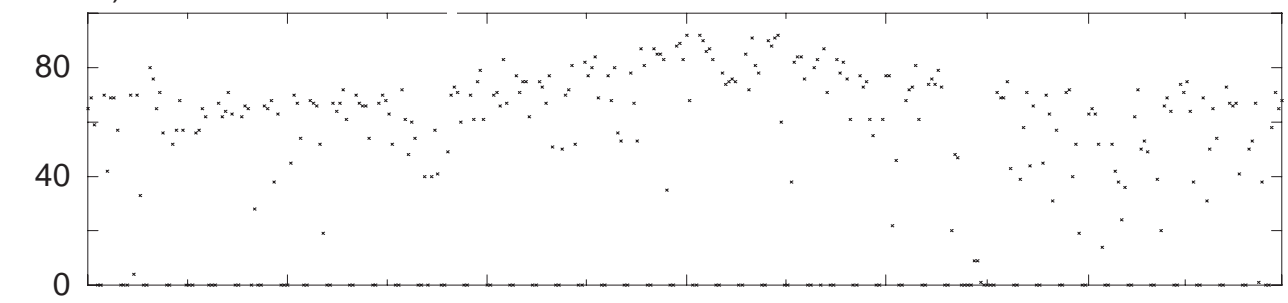

e) Bottom shear stress ( $N^{-2}$ )

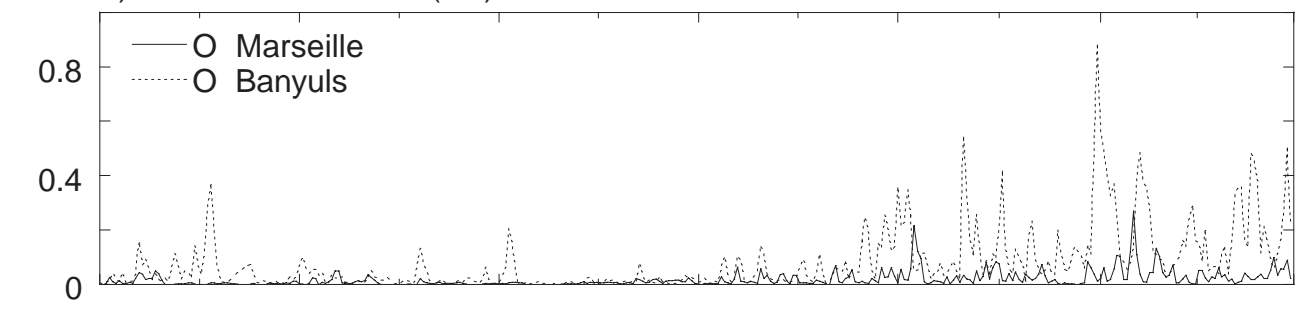

f) Near-bottom density anomaly ( $\left.\mathrm{kg}-\mathrm{in}^{3}\right)$

29

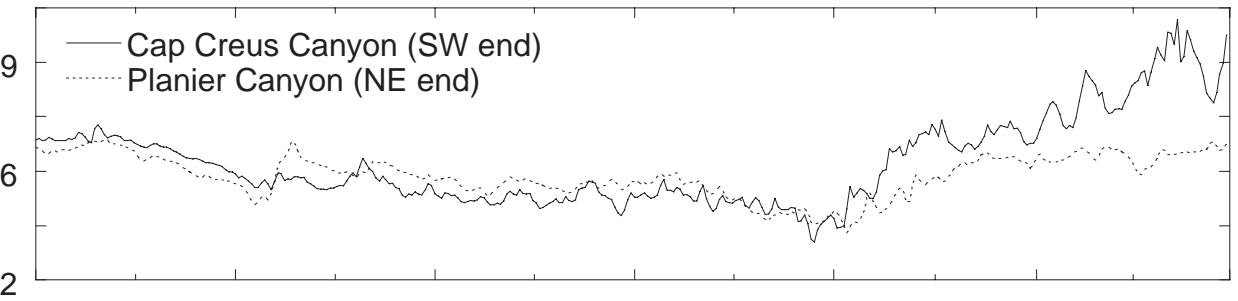

28.2

$610^{3}$ g) Water ux across the shelf break $\left.{ }^{3} \mathrm{ra}^{-1}\right)$

310

$-310$

$-610$

$\begin{array}{lllllll}\text { Apr } 98 & \text { J J } 98 & \text { Aug } 98 & \text { Oct } 98 & \text { Dec } 98 & \text { Feb } 99 & \text { Apr } 99\end{array}$

Ferre et al. Figure 3 


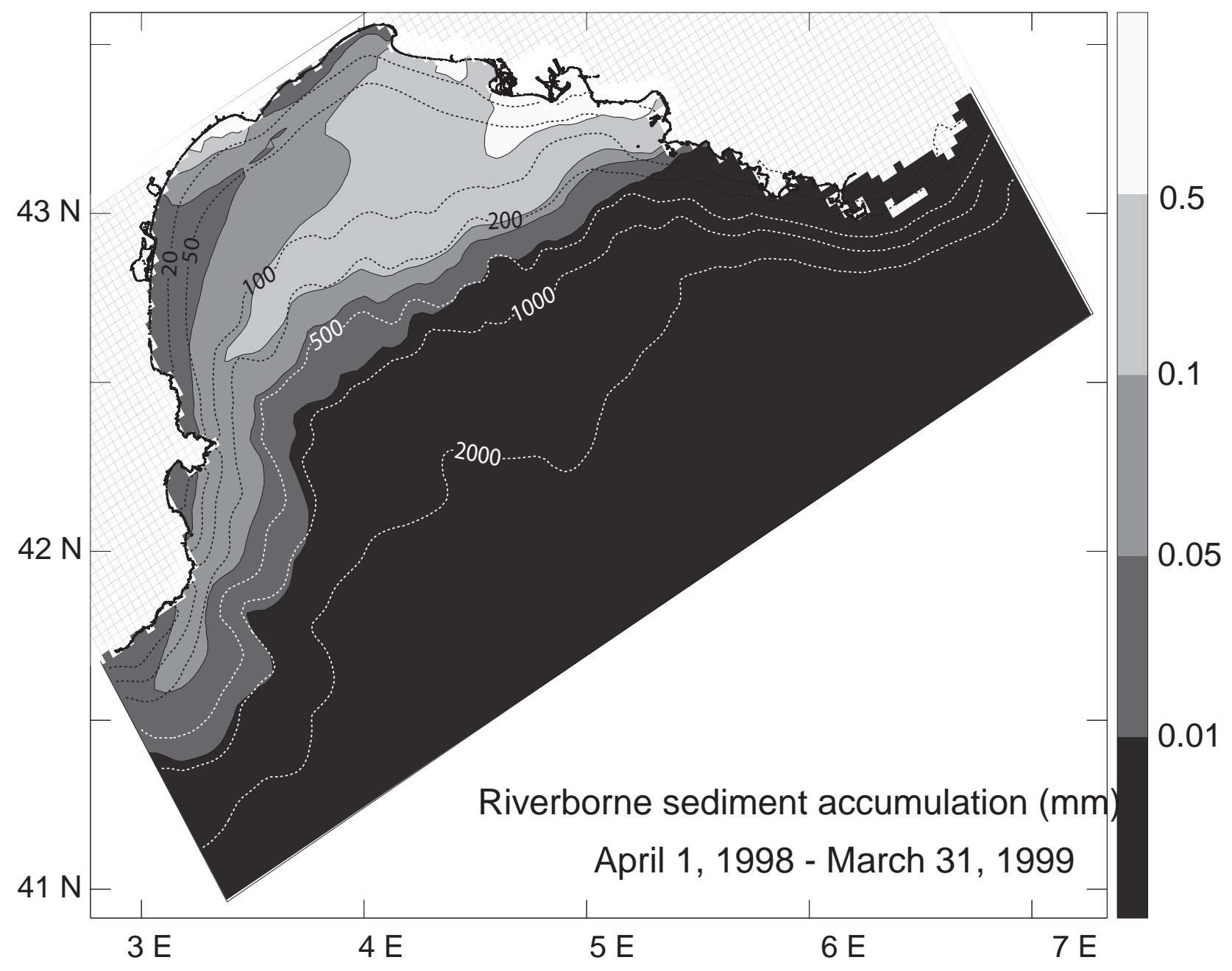

Ferre et al. Figure 4 


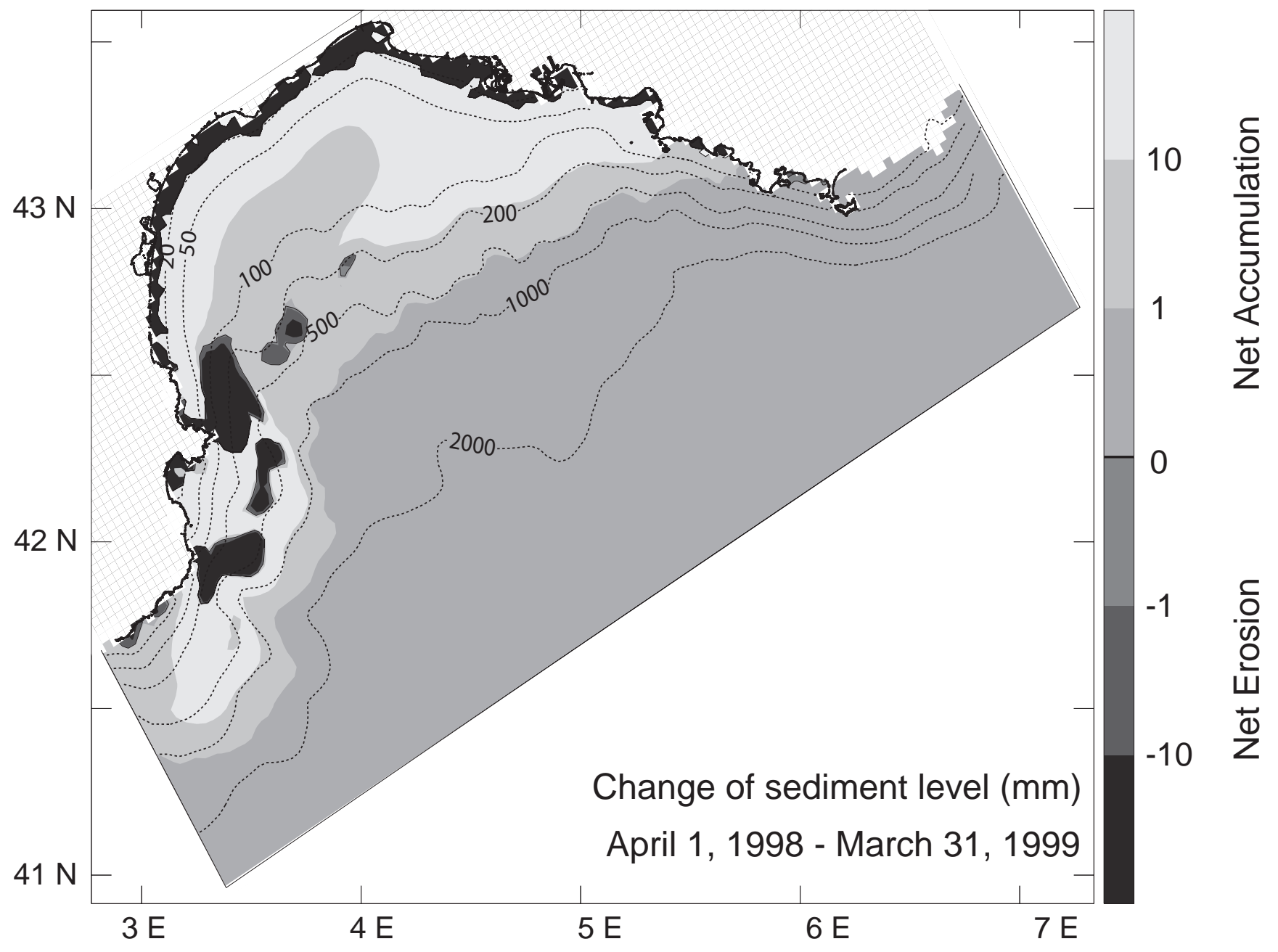

Ferre et al. Figure 6 


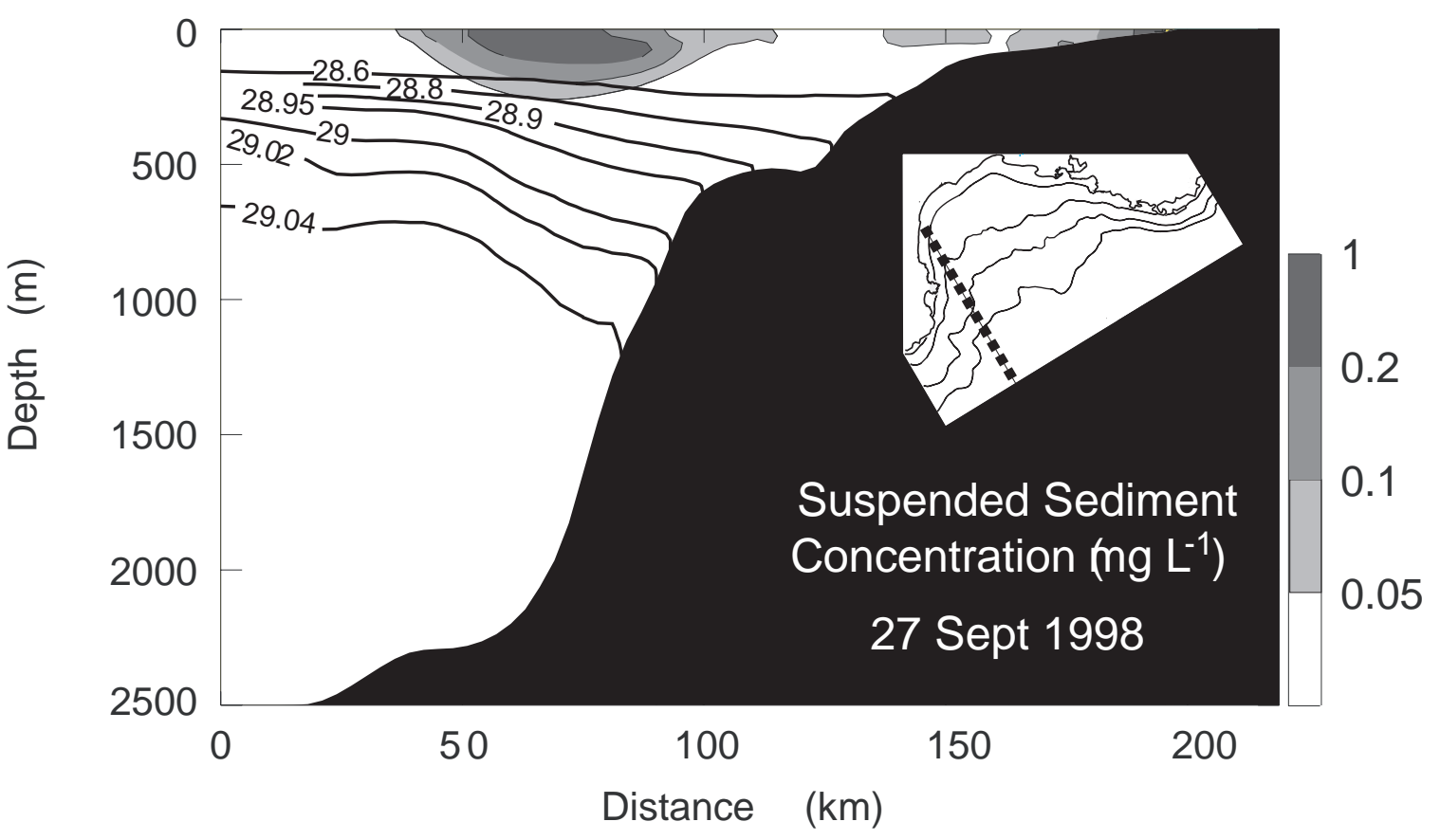

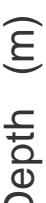

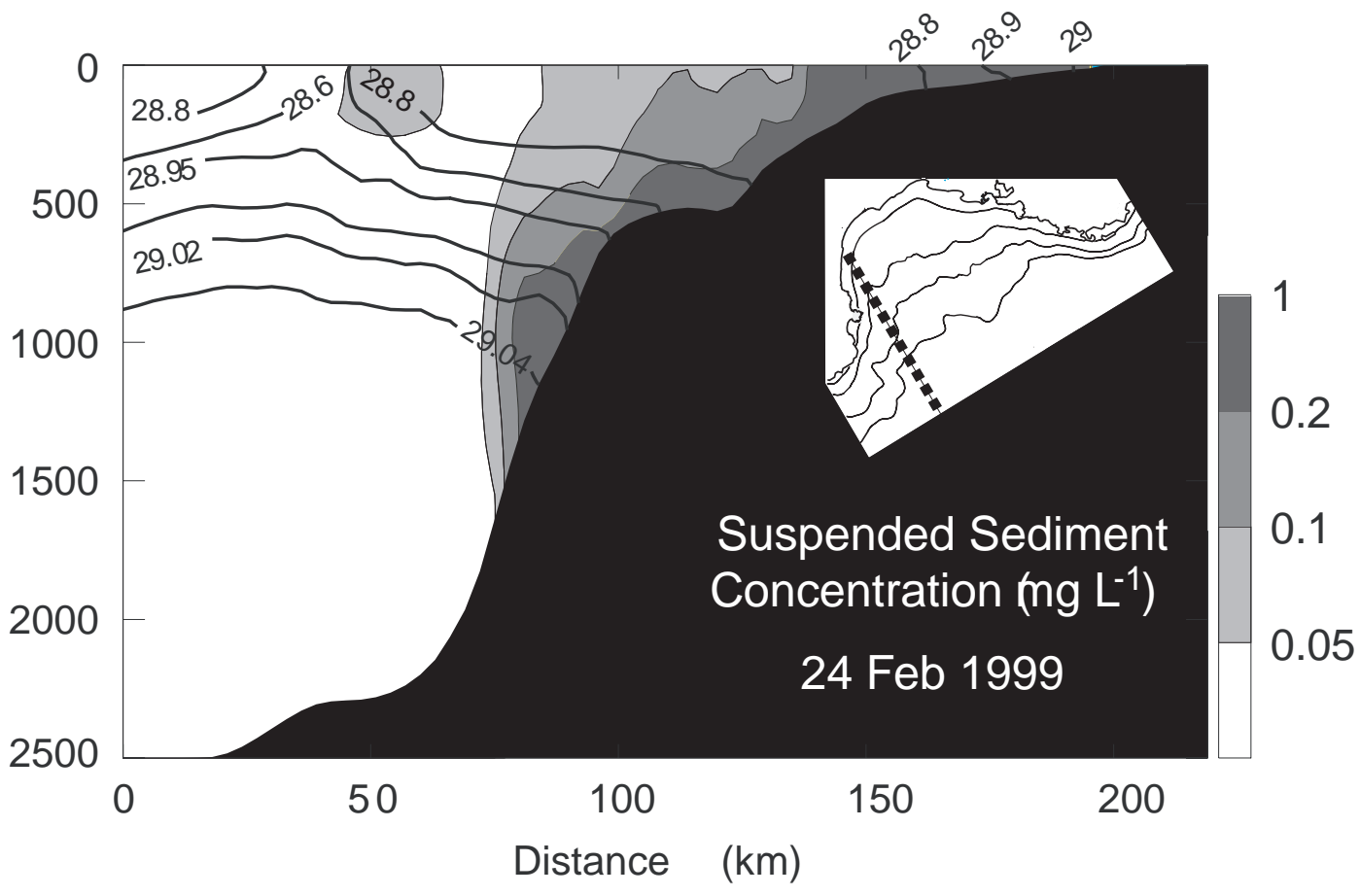

Ferre et al. Figure 7 


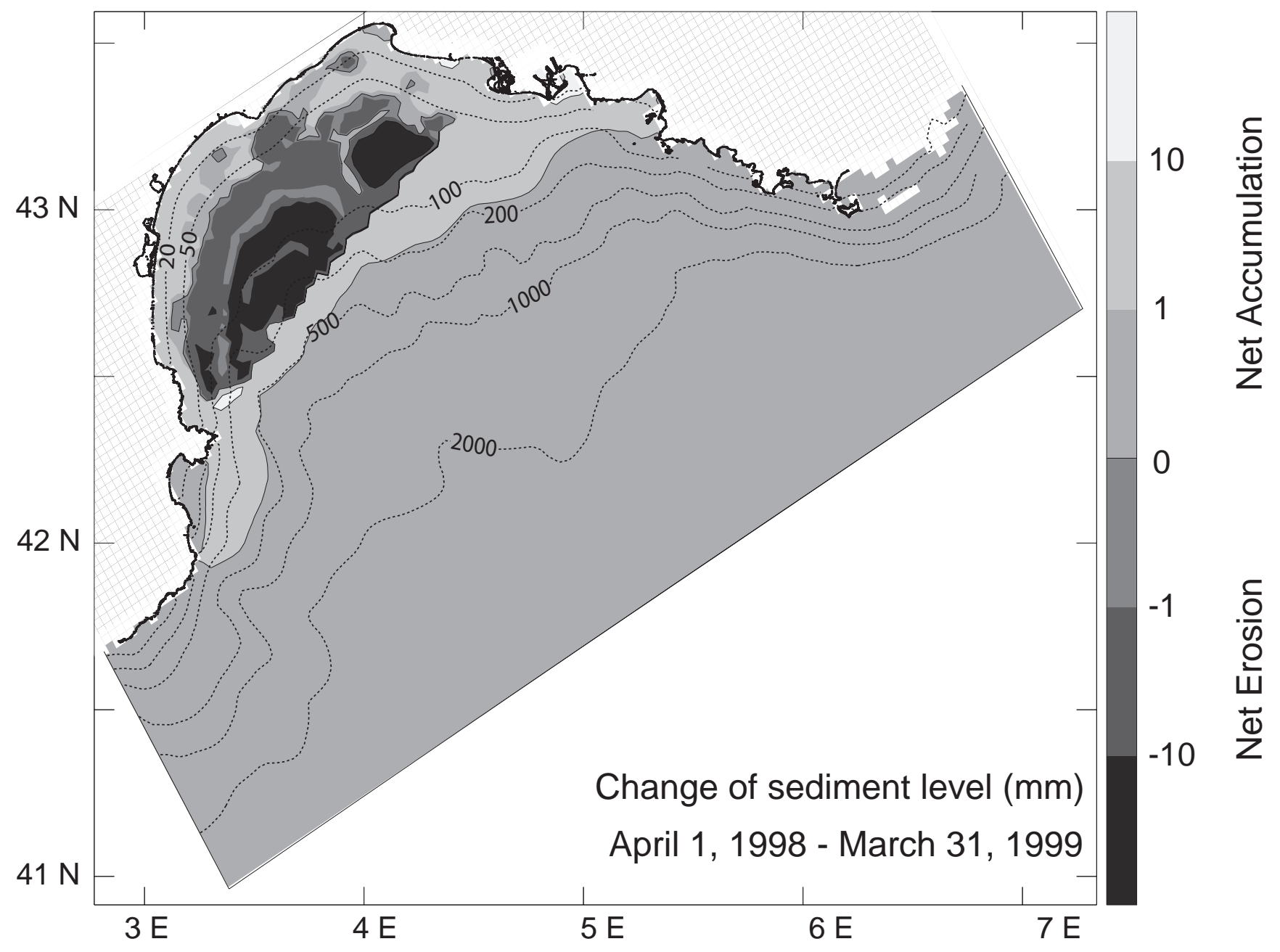

Ferre et al. Figure 9 


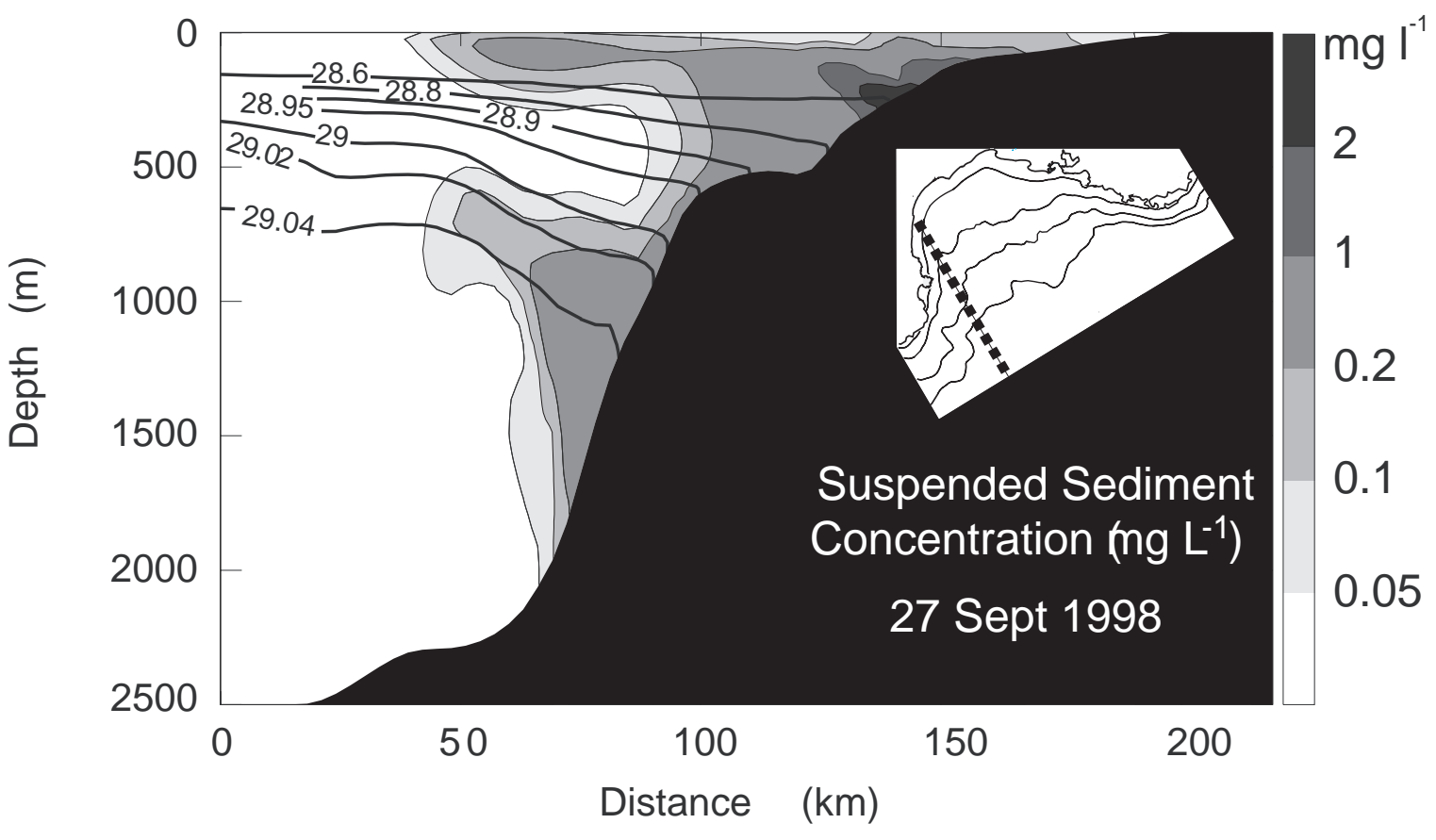

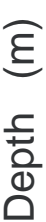

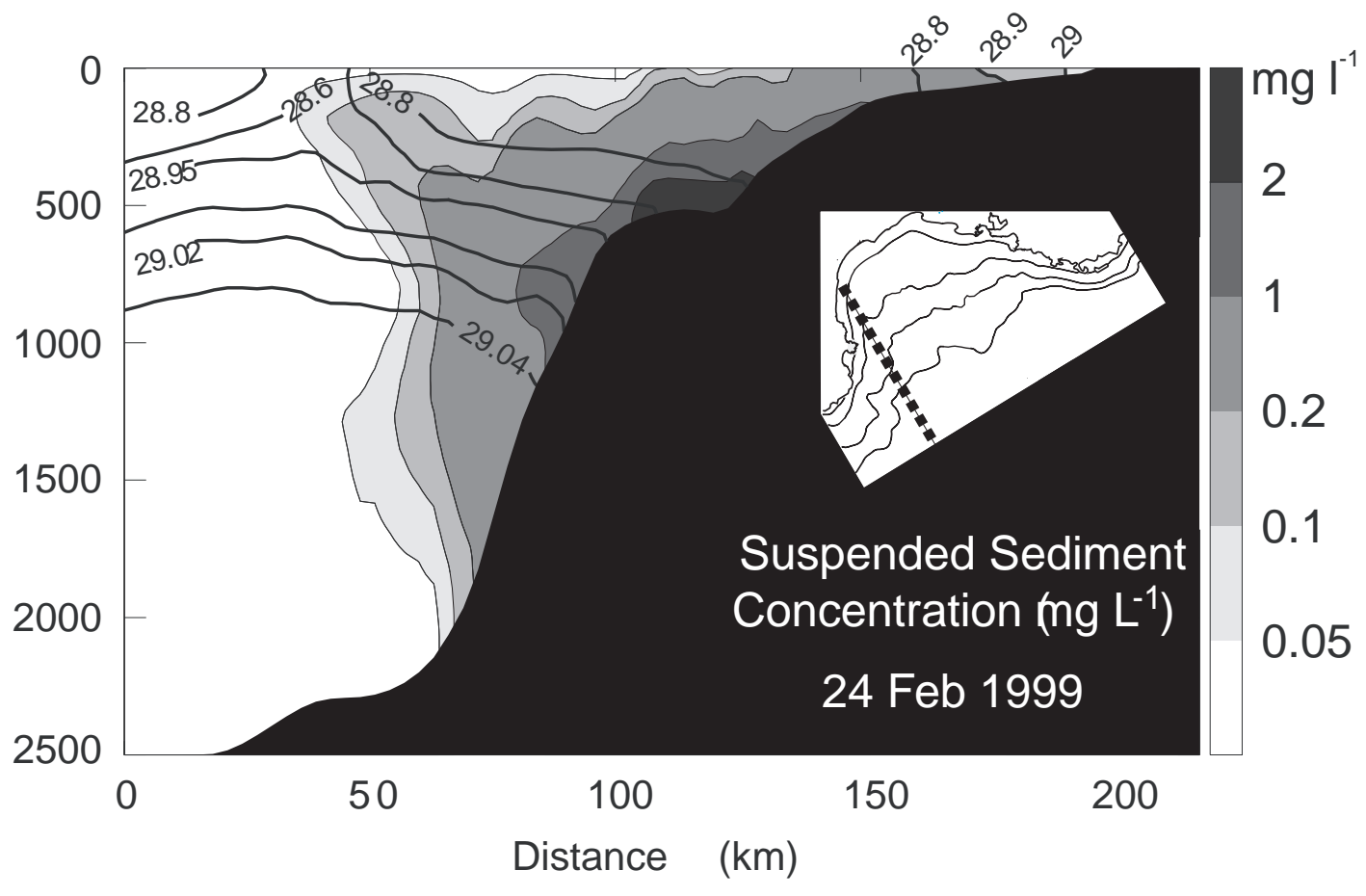

Ferre et al. Figure 10 

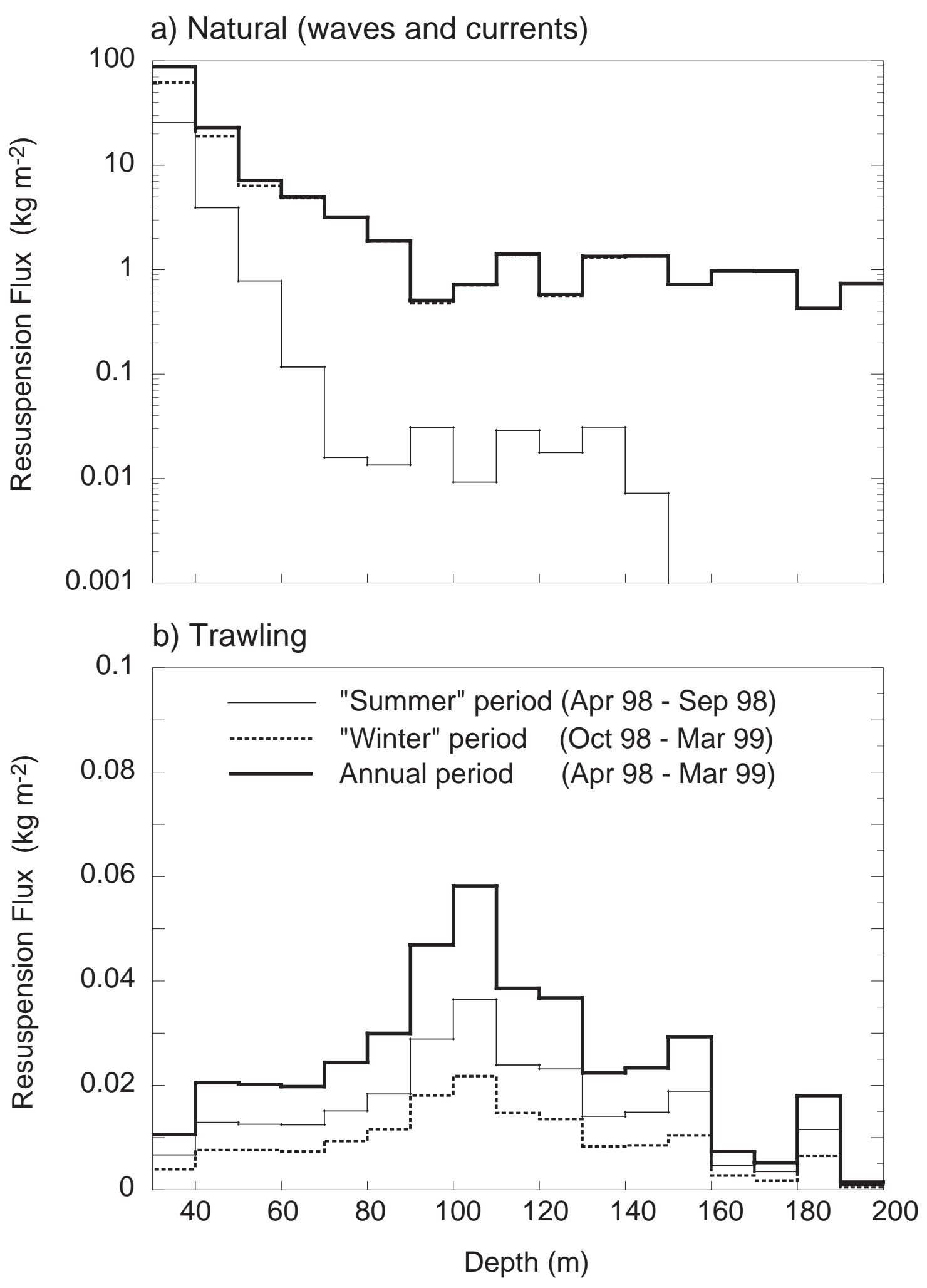

Ferre et al. Figure 11 


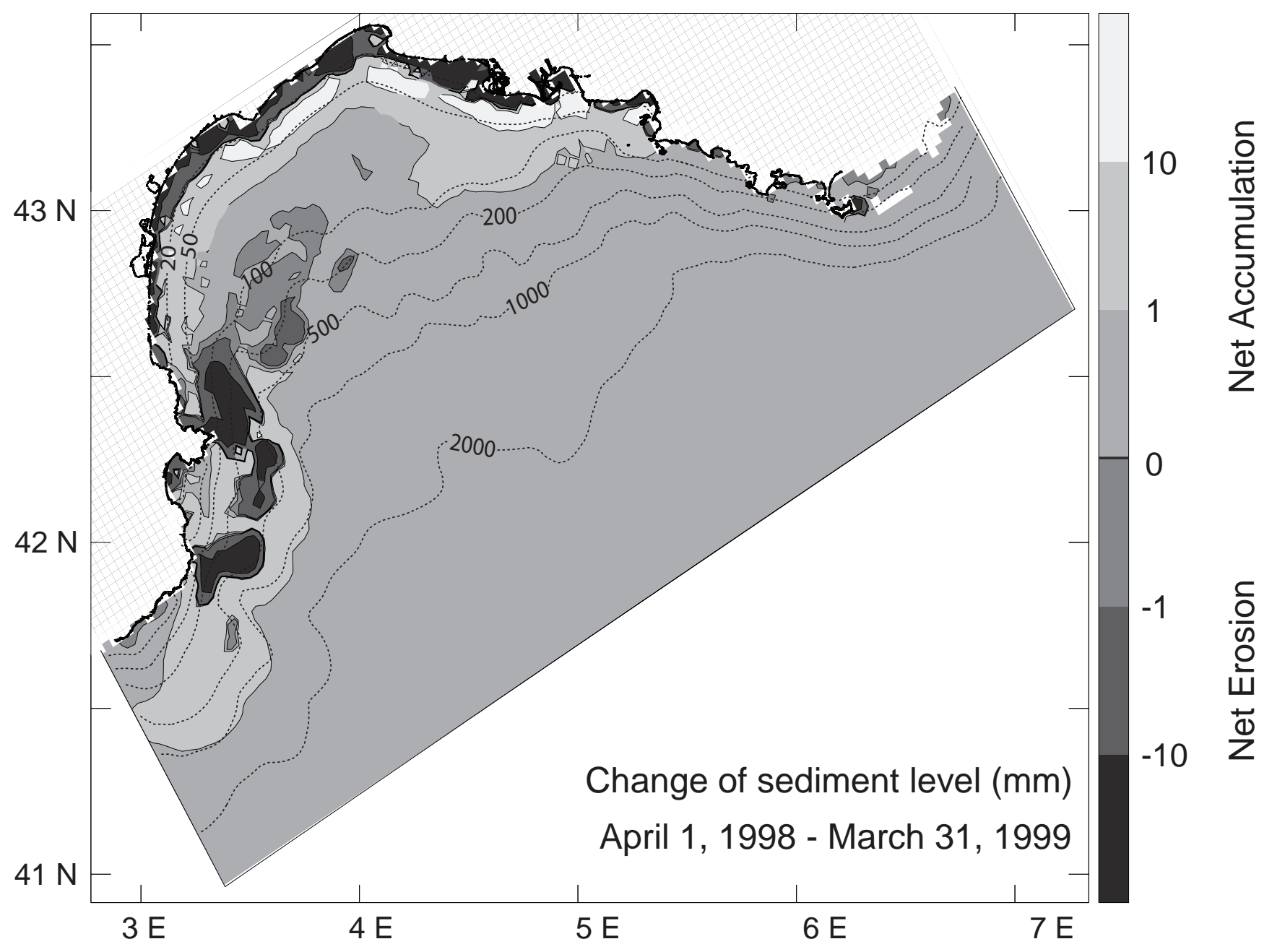

Ferre et al. Figure 12 

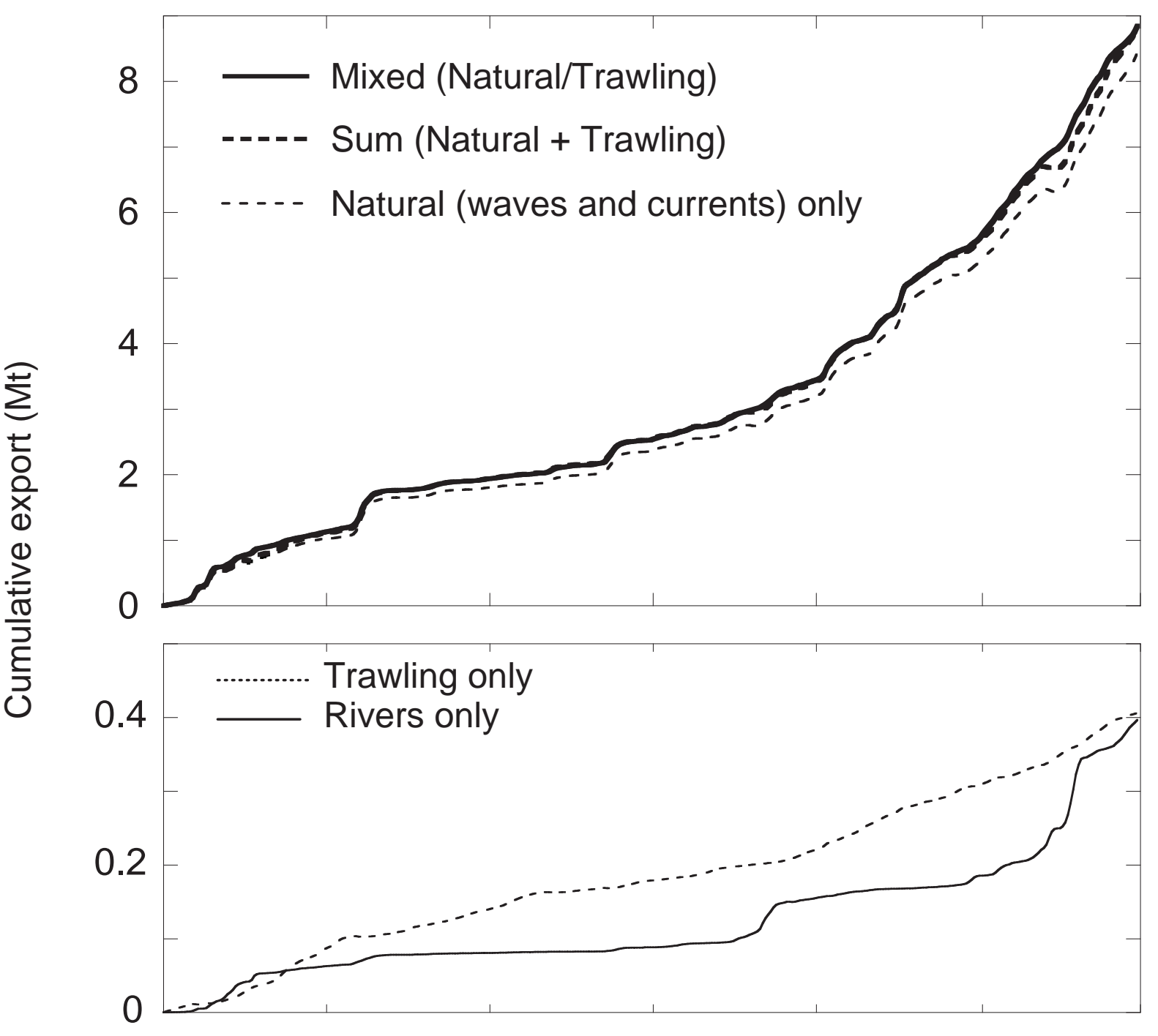

$\begin{array}{lllllll}\text { Apr } 98 \text { J un } 98 \text { Aug } 98 \text { Oct } 98 \text { Dec } 98 & \text { Feb } 99 & \text { Apr } 99\end{array}$ 